\title{
Antiviral Potential of the Antimicrobial Drug Atovaquone against SARS-CoV-2 and Emerging Variants of Concern
}

Madalina Elena Carter-Timofte, Rozanne Arulanandam, Naziia Kurmasheva, Kathy Fu, Geneviève Laroche, Zaid Taha, Demi van der Horst, Lena Cassin, Renée M. van der Sluis, Enrico Palermo, Daniele Di Carlo, David Jacobs, Glib Maznyi, Taha Azad, Ragunath Singaravelu, Fanghui Ren, Anne Louise Hansen, Manja Idorn, Christian K. Holm, Martin R. Jakobsen, Julien van Grevenynghe, John Hiscott, Søren R. Paludan, John C. Bell, Jean Seguin, Luc A. Sabourin, Marceline Côté, Jean-Simon Diallo, Tommy Alain, and David Olagnier*

Cite This: https://doi.org/10.1021/acsinfecdis.1c00278

Read Online

ABSTRACT: The antimicrobial medication malarone (atovaquone/proguanil) is used as a fixed-dose combination for treating children and adults with uncomplicated malaria or as chemoprophylaxis for preventing malaria in travelers. It is an inexpensive, efficacious, and safe drug frequently prescribed around the world. Following anecdotal evidence from 17 patients in the provinces of Quebec and Ontario, Canada, suggesting that malarone/ atovaquone may present some benefits in protecting against COVID-19, we sought to examine its antiviral potential in limiting the replication of SARSCoV-2 in cellular models of infection. In VeroE6 expressing human TMPRSS2 and human lung Calu-3 epithelial cells, we show that the active compound atovaquone at micromolar concentrations potently inhibits the replication of SARS-CoV-2 and other variants of concern including the alpha, beta, and delta variants. Importantly, atovaquone retained its full antiviral activity in a primary human airway epithelium cell culture model. Mechanistically, we demonstrate

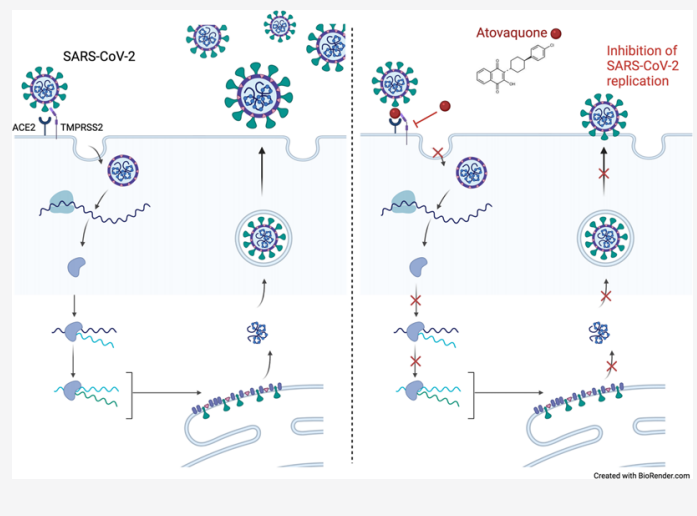
that the atovaquone antiviral activity against SARS-CoV-2 is partially dependent on the expression of TMPRSS2 and that the drug can disrupt the interaction of the spike protein with the viral receptor, ACE2. Additionally, spike-mediated membrane fusion was also reduced in the presence of atovaquone. In the United States, two clinical trials of atovaquone administered alone or in combination with azithromycin were initiated in 2020. While we await the results of these trials, our findings in cellular infection models demonstrate that atovaquone is a potent antiviral FDA-approved drug against SARS-CoV- 2 and other variants of concern in vitro.

KEYWORDS: SARS-CoV-2, coronavirus, atovaquone, variants, drug repurposing, virus

$\mathrm{T}$ he dramatic health and societal impacts of the emerging coronavirus, SARS-CoV-2, continue to be devastating, with the total number of deaths associated with COVID-19 now reaching over 4.8 million people worldwide. In many areas, healthcare systems are overwhelmed and although vaccines have been developed, ${ }^{1-4}$ vaccine access inequity and the emergence of novel variants with potential vaccine escape capacities are urging the repurposing of already clinically approved, safe, accessible, and active drugs against SARS-CoV2 .

Atovaquone, the active compound of malarone, has been used in humans since 1999, both as a treatment for Pneumocystis jirovecii pneumonia ${ }^{5,6}$ and as a fixed-dose combination with proguanil for treating and preventing malaria. ${ }^{7,8}$ Atovaquone is an ubiquinol analogue, which targets the formation of the $b c 1$ complex as part of the mitochondrial electron transport chain and leads to a collapse in mitochondrial functions. ${ }^{9-12}$ Importantly, atovaquone only affects parasitic mitochondrial functions without inhibiting the mammalian mitochondrial $b c_{1}$ complex. ${ }^{10}$ Treatment with this compound further results in changes in the concentration of metabolites within the pyrimidine biosynthetic pathway as well as the inhibition of purine biosynthesis. ${ }^{12-15}$ Given its excellent safety profile, atovaquone is a popular and widely

Received: $\quad$ May 21, 2021 
used Food and Drug Administration (FDA)-approved drug for the treatment of malaria.

As recently as 2019, however, atovaquone has also been described as a potential broad-spectrum antiviral drug, particularly active against arboviruses including Zika virus, chikungunya virus, and dengue virus. ${ }^{16,17}$ In the case of viral infections, atovaquone is believed to act early against infections, potentially by targeting viral RNA replication, through a mechanism involving the inhibition of the pyrimidine biosynthesis pathway, ${ }^{16}$ or viral entry, by interfering with viral glycoprotein-mediated membrane fusion. ${ }^{17}$ Additionally, atovaquone was demonstrated to have some efficacy in vitro in limiting the infectivity of the coronavirus MERSCoV. ${ }^{18}$

Early on and as the pandemic progressed in the provinces of Quebec and Ontario in Canada, several anecdotal observations suggested that patients taking the antimalaria medication had either beneficial or protective effects against COVID-19. This was observed in multiple contexts (each case is described in the Supplemental Text), including first-line responders working in outbreak establishments as well as elderly individuals. In particular, malarone regimen seemed to revert the COVIDpositive status in several patients. In addition, malarone taken prophylactically appeared to be effective at protecting hospital workers and long-term care home employees for extended periods against SARS-CoV-2 infections where severe outbreaks occurred. Follow-up investigations found that none of the patients reported any serious side effects with malarone or atovaquone taken in a prophylactic or therapeutic manner. Notably, none tested positive following or while being on malarone despite some being at elevated risk. These anecdotal cases proposed that the active compound atovaquone may be of use in preventing coronavirus infection or alleviating disease symptoms. Importantly, two clinical trials, one at the University of Texas Southwestern Medical Center and the other at the HonorHealth Research Institute in Arizona, were initiated last year (2020) to test atovaquone in combination with azithromycin in patients with confirmed COVID-19. One trial is now completed but the results are yet to be published (NCT04456153), while the other continues to actively recruit participants (NCT04339426).

Collectively, these clinical observations prompted us to evaluate the antiviral capacity of atovaquone in relevant cellular models of infection against the original SARS-CoV-2 and other variants of concern. Our findings demonstrate the strong antiviral potential of this FDA-approved molecule in limiting the infectivity and replication of the original SARS-CoV-2 and other variants of concern in lung epithelial cells and a primary human airway epithelial cell culture model in vitro. Although this study does not directly confirm the efficacy of the drug in humans, the potent antiviral effects obtained in vitro suggest that atovaquone/malarone may represent an effective therapeutic option repurposed for the treatment of COVID-19, particularly to protect frontline workers and/or high-risk populations.

\section{RESULTS}

Antiviral Potential of Atovaquone on SARS-CoV-2Pseudotyped Vesicular Stomatitis Virus (VSV) and WildType (wt) VSV. In light of the anecdotal observations made on different patients included in the described "off-label use of malarone against COVID-19" (see Supplemental Text), we sought, first, to assess the antiviral potential of atovaquone following infection with SARS-CoV-2-spike-pseudotyped VSV and wtVSV, both expressing GFP. VeroE6 cells were treated with various concentrations of atovaquone. Fifteen minutes later, the cells were infected with wtVSV-spike or wtVSV expressing GFP in the presence of the drug. Eleven hours postinfection, cells were imaged for GFP as a proxy for infection rate. In addition, the cellular viability was determined $48 \mathrm{~h}$ postinfection to assess viral replication and lysis. The same experiment was repeated on VeroE6 expressing hACE2 and hTMPRSS2. The results clearly showed a significant and dose-dependent block in the infectivity of both wtVSV and VSV-spike in VeroE6, and even more so in VeroE6 cells expressing hACE2-hTMPRSS2, without any change in levels of cytotoxicity displayed by the drug alone or in combination with the virus (Figure 1). Of note, wtVSV was more toxic on its own than VSV-spike and a slight increase in viability with atovaquone was noticed due to a reduction in virus-induced cytotoxicity.

Antiviral Potential of Atovaquone on an Early SARSCoV-2 Isolate. Having established the potent antiviral effect of atovaquone on wtVSV and VSV-spike, we set out to determine a concentration that could be optimal in inhibiting SARS-CoV-2 replication in vitro. VeroE6 cells expressing human TMPRSS2 were pretreated with increasing doses of atovaquone followed by SARS-CoV-2 infection (strain \#291.3 FR-4286 isolated early in 2020 from a patient in Freiburg, Germany) in the presence of the drug. A concentration of 10 $\mu \mathrm{M}$ atovaquone was most efficient in inhibiting viral replication, as determined by quantitative polymerase chain reaction (qPCR) analysis of the SARS-CoV-2 genome $\left(\mathrm{IC}_{50}=\right.$ $2.7 \mu \mathrm{M}$ ) (Figure $2 \mathrm{~A}$ ). Importantly, none of the concentrations tested appeared to be toxic to the cells when analyzed using the lactate dehydrogenase $(\mathrm{LDH})$ release assay (Figure $2 \mathrm{~B}$ ). In order to determine if atovaquone is able to inhibit the release of infectious virus, supernatants from VeroE6 hTMPRSS2 cells infected with SARS-CoV-2 were collected following infection and atovaquone treatment. An impressive $10^{5}-10^{6} \log$-fold reduction in the production of viral progeny was observed in atovaquone-treated cells, as determined by the TCID50 assay (Figure 2C).

Furthermore, immunofluorescence staining showed an almost complete absence of the intracellular SARS-CoV-2 spike protein following atovaquone treatment in Vero hTMPRSS2 (Figure S1A). Importantly, the antiviral effect of atovaquone was retained in the human lung epithelial cell line Calu-3 with more than a 100 -fold reduction in viral genome expression (Figure S1B). A dose escalation experiment of the drug showed an $\mathrm{IC}_{50}$ of $29.7 \mu \mathrm{M}$ in the same cell line (Figure 2D). Again, no apparent toxicity was noticed for the antiviral active doses in this cellular model (Figure 2E). The release of progeny virus was also reduced by roughly 10,000-fold based on TCID50 analysis of infected cell supernatants (Figure $2 \mathrm{~F}$ ). The dampened SARS-CoV-2 infectivity in the presence of atovaquone led to reduced virus-induced cytotoxicity of the infected Calu-3 cells as determined by immunostaining for cleaved caspase- 3 and by flow cytometry for live/dead staining (Figure 2G,H).

Antiviral Potential of Atovaquone against Mild Coronaviruses and SARS-CoV-2 Variants of Concern. Our experimental data suggest that atovaquone is a promising antiviral agent against infection with the original SARS-CoV-2 strain. Since then, several variants have been identified to circulate globally, which have raised concerns regarding their 


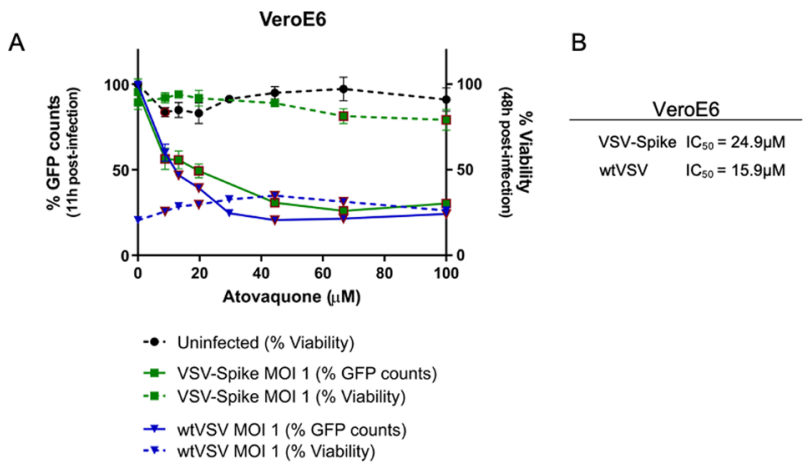

C
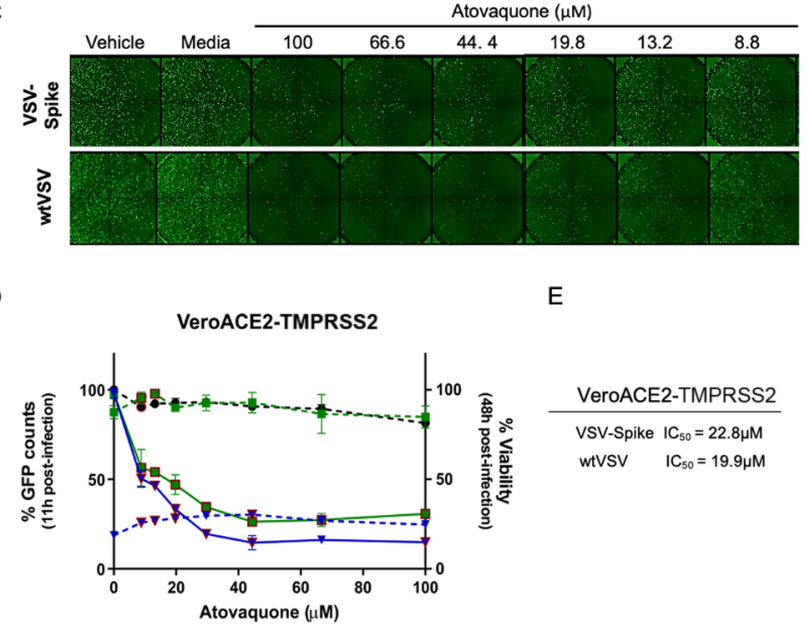

-. Uninfected (\% Viability)

- VSV-Spike MOI 1 (\% GFP counts)

-. VSV-Spike MOI 1 (\% Viability)

* wtVSV MOI 1 (\% GFP counts)

-F. wtVSV MOI 1 (\% Viability)

F

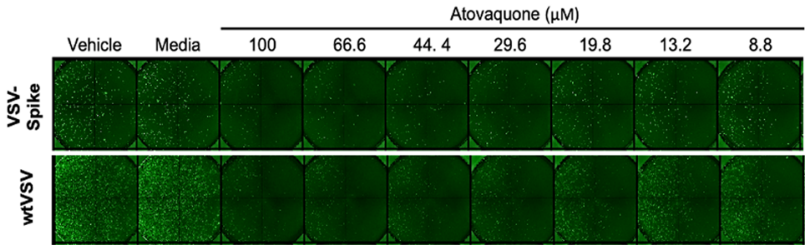

Figure 1. Atovaquone restricts wtVSV and VSV-SARS spike infectivity in VeroE6 and VeroE6 hTMPRSS2-hACE2 cells. VeroE6 cells or VeroE6 cells stably transduced with hACE2 and TMPRSS2 were seeded at $2.5 \times 10^{4}$ cells $/ \mathrm{cm}^{2}$ in 96-well plates and treated with various concentrations of atovaquone. Fifteen minutes later, cells were infected at an MOI of 1 with wtVSV-spike (Whelan strain) or wtVSV expressing GFP. Eleven hours postinfection, cells were imaged and GFP counts were obtained using the ArrayScan High Content Platform (Thermo Scientific Cellomics). Forty-eight hours postinfection, the viability was determined using resazurin sodium salt (Sigma-Aldrich). (A, D) Graphs show \% GFP counts (left axis) normalized to untreated, infected conditions for VSV-spike (green squares, $N=5$ ) and wtVSV (blue triangles, $N=2$ ). The right axis shows \% viability normalized to untreated, uninfected conditions for atovaquone alone (black circles, $N=3$ ), atovaquone-treated, VSVspike-infected cells (green squares, $N=5$ ), or atovaquone-treated, wtVSV-infected cells (blue triangles, $N=2$ ). Symbols boxed in red demonstrate a significant difference over untreated cells $(p<0.05$ and $p<0.005$ for all atovaquone-treated, VSV-spike-infected GFP counts using a $t$-test). Representative fluorescent images are shown for each condition $(\mathrm{C}, \mathrm{F})$, and $\mathrm{IC}_{50}$ values are indicated for VSV-spike and wtVSV $(\mathrm{B}, \mathrm{E})$. Vehicle $=$ medium containing the atovaquone-diluting agent, DMSO. Media = culture medium only. increased infectivity and the efficacy of the current vaccines against such variants. We aimed to investigate the antiviral capabilities of atovaquone against different variants of concern including the cluster 5 variant (mink variant), alpha variant, beta variant, and delta variant. Treatment of VeroE6 hTMPRSS2 efficiently inhibited SARS-CoV-2 viral gene expression with the original viral strain and the mink variant (Figure 3A). Interestingly, the antiviral capacity of atovaquone was also retained with the alpha and beta variants (Figure $3 \mathrm{~B}$ ). Importantly and despite displaying a slightly lower antiviral activity, atovaquone was still capable of drastically inhibiting SARS-CoV-2 delta variant gene expression (Figure 3B). Furthermore, immunofluorescence staining showed an almost complete reduction of the intracellular SARS-CoV-2 spike protein following atovaquone treatment for the different variants tested (Figure 3C). Finally, to investigate if atovaquone had a broad antiviral activity against other coronaviruses, the same experiments were performed on two mild human coronaviruses OC43 and 229E. Treatment of Huh-7 and Caco- 2 cells with atovaquone reduced the viral gene expression of both OC43 and 229E viruses. The antiviral activity of atovaquone was more pronounced against OC43 than 229E, without displaying cytotoxicity at the dosage used (Figure 3D-F). These results provide further support to the use of atovaquone as a potent and broad-spectrum antiviral agent, which can be potentially used against SARS-CoV-2 variants of concern.

Atovaquone Suppresses SARS-CoV-2-Induced Inflammatory Responses. COVID-19 pathogenesis is strongly associated with an imbalanced proinflammatory cytokine response contributing to disease development and damage in the lungs. ${ }^{19-21}$ As a consequence, we investigated if atovaquone also inhibited the inflammatory cytokine gene expression induced following virus infection. SARS-CoV-2 infection in lung Calu-3 cells increased the expression of inflammatory and antiviral markers including IFNB1, C-X-C motif chemokine 10 (CXCL10), interferon-stimulated gene 15 (ISG15), tumor necrosis factor alpha (TNFA), interleukin-6 (IL-6), and tumor necrosis factor alpha-induced protein 3 (TFNAIP3) (Figure 4). Interestingly, this wave of virusinduced inflammation was abrogated by atovaquone pretreatment of Calu-3 cells (Figure 4A,B). To test whether this inhibition in SARS-CoV-2-induced inflammation was an indirect consequence from a reduction of viral RNA sensing by intracytoplasmic receptors, or if atovaquone truly had the capacity to modulate early antiviral signaling events, a drug treatment was performed in a context of stimulation with a synthetic sequence-optimized RIG-I agonist. ${ }^{22}$ Pretreatment for $2 \mathrm{~h}$ with atovaquone inhibited RIG-I-induced antiviral gene levels (IFNB, CXCL10, and ISG15) but not inflammatory gene levels (TNFA, IL6, or TNFAIP3) (Figure 4C,D). Additionally, the same pretreatment for $2 \mathrm{~h}$ with atovaquone dose-dependently reduced the responsiveness to the RIG-I agonist M8 in human Calu-3 cells, as shown by the reduction in the phosphorylation status of the transcription factor STAT1 and the subsequent inhibition of induction of various interferon-stimulated proteins such as IFIT1 and ISG15 (Figure 4E). Quite surprisingly, phosphorylation of the kinase TBK1 and the transcription factor IRF3 was not altered by atovaquone suggesting that only the type I IFN signaling arm was affected by the drug treatment in response to the RNA agonist. Interestingly, atovaquone pretreatment also altered the responsiveness to IFNB1 treatment as demonstrated by the 
A
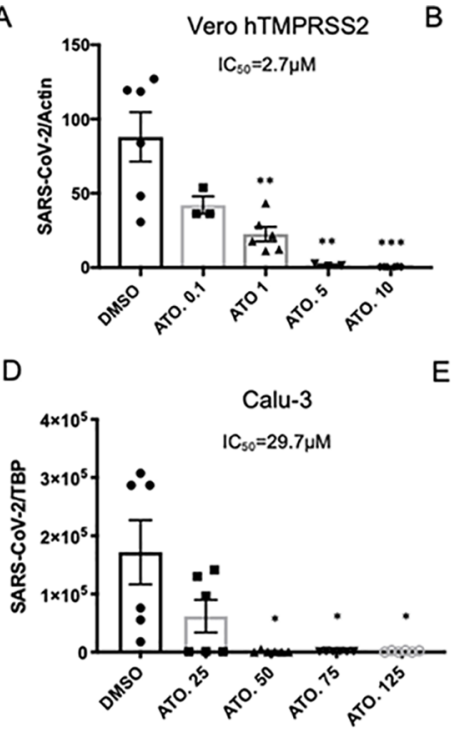
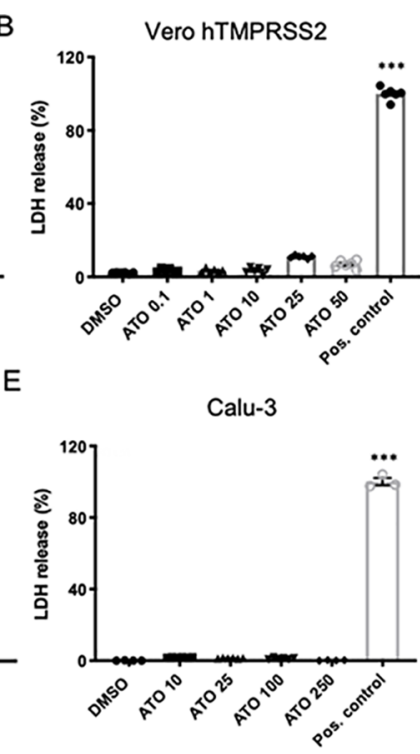

C

Vero hTMPRSS2
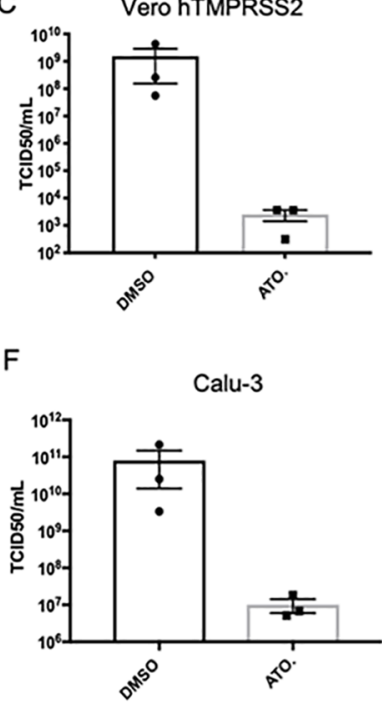

G

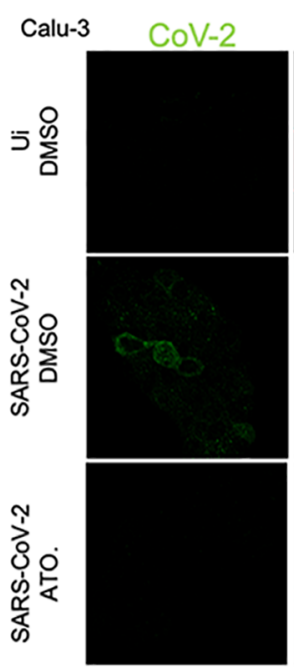

F-Actin
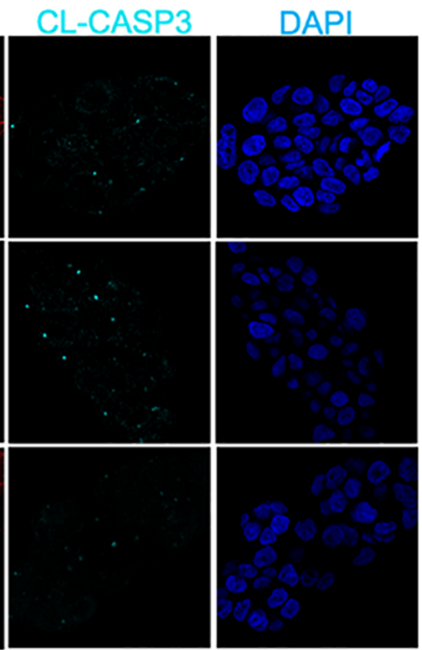

Merge
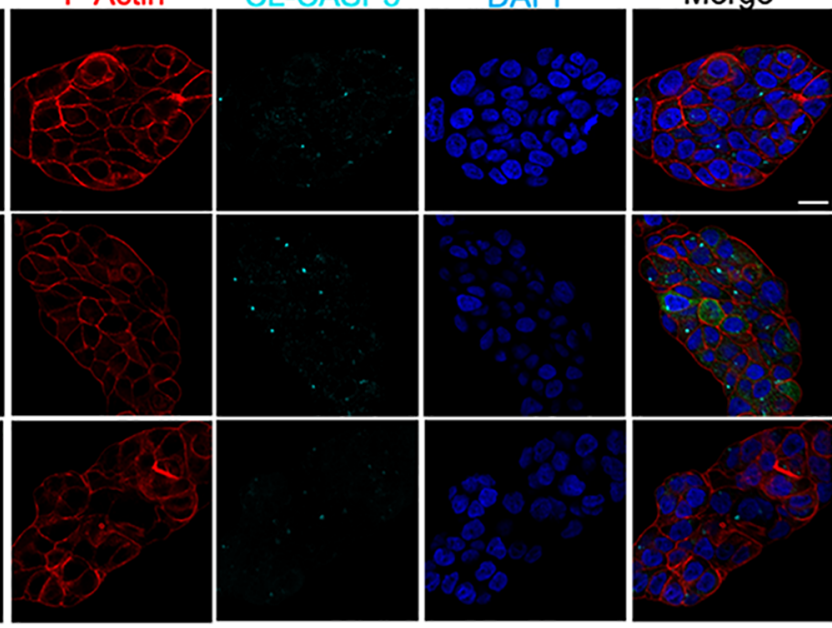

$\mathrm{H}$
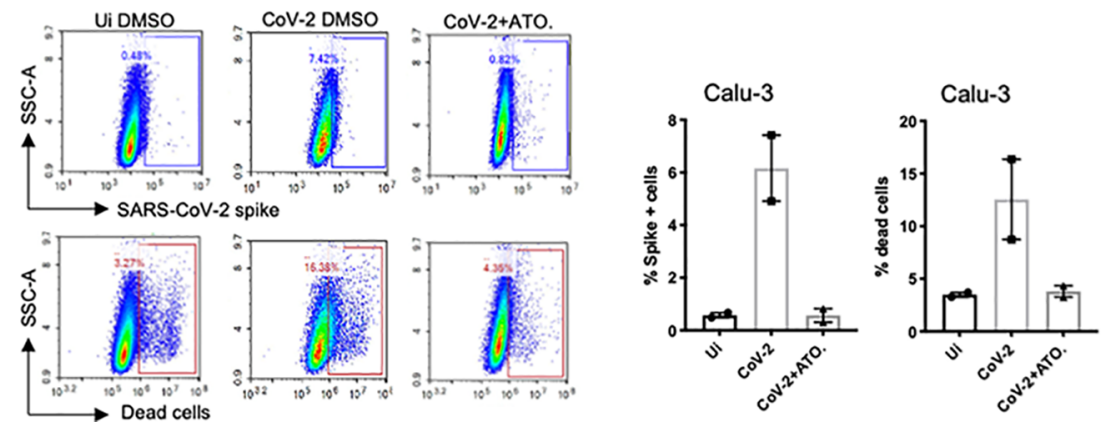

Figure 2. Atovaquone restricts the infection and replication of original SARS-CoV-2 in vitro. (A) VeroE6 cells expressing hTMPRSS2 were pretreated for $2 \mathrm{~h}$ with increasing doses of atovaquone. The cells were subsequently infected with SARS-CoV-2 (MOI of 0.1$)$ for $48 \mathrm{~h}$. The SARSCoV-2 RNA levels were quantified by qPCR. Data are the means \pm SEM from two experiments performed in triplicate for DMSO and ATO. 1 and 10 and one experiment in triplicate for ATO. 0.1 and 5. (B) Atovaquone cytotoxicity was assessed over a $48 \mathrm{~h}$ period time using an LDH assay and an increasing dosage of the drug in VeroE6 hTMPRSS2 cells. Data are the means \pm SEM from two experiments performed in triplicate. (C) VeroE6 hTMPRSS2 cells were pretreated for $2 \mathrm{~h}$ with atovaquone $(50 \mu \mathrm{M})$ and subsequently challenged with SARS-CoV-2 (MOI of 0.1$)$ for $48 \mathrm{~h}$. Virus replication was assessed in the supernatants of the infected cells by a TCID50 assay. Data are the means \pm SEM from one representative experiment performed in triplicate. (D) Calu-3 cells were pretreated for $2 \mathrm{~h}$ with different concentrations of atovaquone. Cells were subsequently infected with SARS-CoV-2 (MOI of 0.1 ) for $48 \mathrm{~h}$. SARS-CoV-2 RNA levels were quantified by qPCR. Data are the means \pm SEM from two experiments performed in biological triplicates. (E) The atovaquone cytotoxicity was assessed over a $48 \mathrm{~h}$ period time using an LDH assay and an increasing dosage of the drug in Calu-3 cells. Data are the means \pm SEM from two experiments performed in triplicate. (F) Calu-3 cells were pretreated for $2 \mathrm{~h}$ with atovaquone $(100 \mu \mathrm{M})$ and subsequently challenged with SARS-CoV-2 (MOI of 0.1$)$ for 48 h. Virus replication was assessed in the supernatants of the infected cells by a TCID50 assay. Data are the means \pm SEM from two experiments performed in triplicate. The experiment was repeated twice with a similar trend. (G). Calu-3 cells were seeded on glass cover slips before $2 \mathrm{~h}$ of treatment with atovaquone (100 $\mu \mathrm{M}$ ) and subsequent infection with SARS-CoV-2 (MOI of 0.1). The SARS-CoV-2 spike protein and cleaved caspase-3 were visualized using 
Figure 2. continued

immunostaining and confocal imaging. Nuclei were stained using DAPI and F-Actin using Phalloidin. Scale $=20 \mu \mathrm{m}(\mathrm{H})$ Calu-3 cells were stimulated for $2 \mathrm{~h}$ with atovaquone $(50 \mu \mathrm{M})$ before infection with SARS-CoV-2 (MOI of 0.1). The number of SARS-CoV-2 spike + cells and dead + cells was assessed by flow cytometry. The $p$ values were calculated using a $t$-test where $* p<0.05, * * p<0.01, * * * p<0.001$.

reduced phosphorylation of STAT1 and the lowered expression of the antiviral markers ISG15 and IFIT1 (Figure 4F). Overall, these data suggest that atovaquone is a promising SARS-CoV-2 antiviral agent, which is able to inhibit viral replication and virus-induced inflammation at nontoxic concentrations in VeroE6 hTMPRSS2 cells and lung epithelial Calu-3 cells.

Atovaquone Reduces SARS-CoV-2 Infectivity in Primary Human Airway Epithelial Cultures. We further tested the antiviral effect of atovaquone toward the SARSCoV2 alpha variant in primary human airway epithelial (HAE) cultures (Figure 5A). Here, a pretreatment for $2 \mathrm{~h}$ with the drug (Figure 5B) significantly reduced SARS-CoV-2 RNA levels (Figure 5C). Altogether, these results validate the antiviral activity of atovaquone against SARS-CoV-2 in a physiologically relevant primary HAE cell culture model.

Atovaquone Mediates Some of Its Antiviral Activity against SARS-CoV-2 in a TMPRSS2-Dependent Manner. Preprint unpublished work suggested atovaquone as an FDAapproved drug with antiviral potential against SARS-CoV-2 through covalent binding to the SARS-CoV-2 M protein. ${ }^{23} \mathrm{We}$ aimed to determine the step(s) of the viral life cycle targeted by atovaquone by performing a time-of-addition experiment in which atovaquone was added to the media in the presence of the virus during the entry step ( $1 \mathrm{~h}$ viral infection), or at the postentry step ( $1 \mathrm{~h}$ postinfection), or for the entire duration of the infection (Figure 6A). Immunoblotting for the SARS-CoV2 spike protein revealed a clear decrease in protein expression levels across all of the atovaquone treatment conditions following a $48 \mathrm{~h}$ period of SARS-CoV-2 infection, which suggests that one mode of action of atovaquone involves inhibition of the entry step (Figure 6B). To investigate the role in viral entry, we first evaluated whether atovaquone could prevent the association between the receptor-binding domain (RBD) of spike and its cellular receptor ACE2, and we used a recently developed assay that utilizes protein complementation to detect the prevention or disruption of the interaction between the SARS-CoV-2 spike RBD domain and human ACE2. ${ }^{24,25}$ This assay utilizes a split nanoluciferase construct, with each component called Large BiT (LgBiT) or Small BiT (SmBiT), which has been fused to either ACE2, the spike S1 subunit, or RBD. We tested the impact of atovaquone on SARS binding to ACE2 using a variety of constructs, notably the $\mathrm{RBD}$ or $\mathrm{S} 1$ domain from SARS-CoV-2 or the RBD domain from SARS-CoV-1 (Figure 6C). The results showed a significant $\sim 10$-fold reduction in binding between the SARSCoV-2 S1 domain and ACE2 in this assay (Figure 6D); by comparison, this reduction was not observed when proguanil was tested using the same assay (Figure S2). Furthermore, we investigated whether TMPRSS2 is a required factor for driving atovaquone-mediated antiviral effects against SARS-CoV-2. Infectivity of SARS-CoV-2 in different cell lines expressing variable levels of the human cellular serine protease TMPRSS2 was determined by qPCR following atovaquone treatment. Surprisingly, only cells expressing high protein levels of hTMPRSS2 (VeroE6 hTMPRSS2 and Calu-3) (Figure 6E,F and Figure S3) displayed a drastic 1-log or more reduction in viral RNA levels following atovaquone treatment suggesting that atovaquone's antiviral activity is partly dependent on TMPRSS2 (Figure 6G). To further investigate a possible effect of atovaquone on the TMPRSS2 activity, we next tested atovaquone's proteolytic activity using a previously established in vitro enzymatic assay. ${ }^{26}$ Intriguingly, while camostat, a known serine protease inhibitor, completely blocked the TMPRSS2 activity, atovaquone had no significant effect on the protease activity, even at high concentrations (Figure S4). To further test the importance of TMPRSS2 in atovaquone's antiviral activity and confirm that atovaquone can interfere with viral entry, we next generated lentiviral pseudotypes bearing SARS-CoV-2 spike and encoding LacZ. Using the pseudotypes, we measured infection in HEK293T cells expressing hACE2 alone or in combination with hTMPRSS2. As expected, expression of TMPRSS2 redirected entry from a cathepsin, E64d-sensitive pathway to a serine protease, camostat-sensitive pathway (Figure $6 \mathrm{H}$ ). Importantly, atovaquone reduced the infection of SARS-CoV-2 pseudotypes only in cells expressing both hACE2 and hTMPRSS2, suggesting that TMPRSS2 plays at least partially a role in atovaquonemediated antiviral activity (Figure 6H). Since both ACE2 and TMPRSS2 are involved in the activation of the spike protein fusion activity, we sought to evaluate the impact of atovaquone on the ability of SARS-CoV-2 spike to induce cell-cell fusion using a bimolecular fluorescence complementation. In this assay, fragments of the Venus fluorescent proteins are fused with a leucine zipper and expressed separately in effector cells expressing the spike proteins and target cells expressing ACE2 in the presence or absence of TMPRSS2. Coculturing of the spike-expressing effector cells and target cells expressing ACE2 led to an increased fluorescence signal indicative of cell-cell fusion in the absence of TMPRSS2 as reported by others ${ }^{27}$ (Figure 6I). As expected, expression of TMPRSS2 in the target cells enhanced the cell-cell fusion. Importantly, this TMPRSS2-dependent increase in cell fusion was sensitive to camostat and atovaquone (Figure 6I), further supporting a TMPRSS2-dependent antiviral mode of action of the drug.

Our data demonstrate that atovaquone can modestly affect the binding between the SARS-CoV-2 spike RBD domain and the ACE2 receptor but also requires to some extent TMPRSS2 to drive some of its antiviral effects, thus presumably contributing to limiting viral entry. However, our results shown in Figures 1 and $6 \mathrm{~B}$ also suggest a possible more complex antiviral mode of action of the drug that can act against SARS-CoV-2 and other viruses (e.g., VSV) both preand postinfection. Atovaquone has been previously reported to target mitochondrial functions in parasites ${ }^{9-12}$ and we thought to investigate this biological dysfunction as a possible mode of action of the drug in human cells. First, we observed in our cellular system using VeroE6 hTMPRSS2 that atovaquone reduced the mitochondrial activity, as measured using an MTT assay (Figure S5A). This disturbance in mitochondrial activity triggered metabolic rewiring of the cells toward glycolysis visually observed by a characteristic drop in $\mathrm{pH}$ and change in the color media of atovaquone-treated cells (Figure S5B). To investigate whether this drop in $\mathrm{pH}$ or shift toward glycolysis 
A

Vero hTMPRSS2

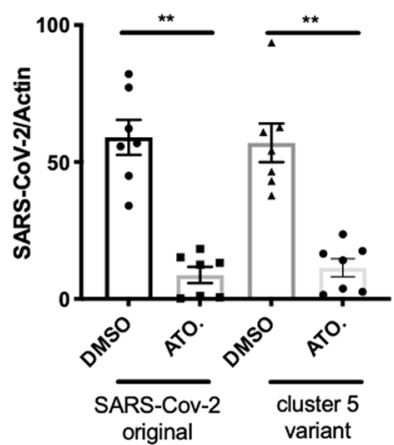

B

\author{
Vero hTMPRSS2
}

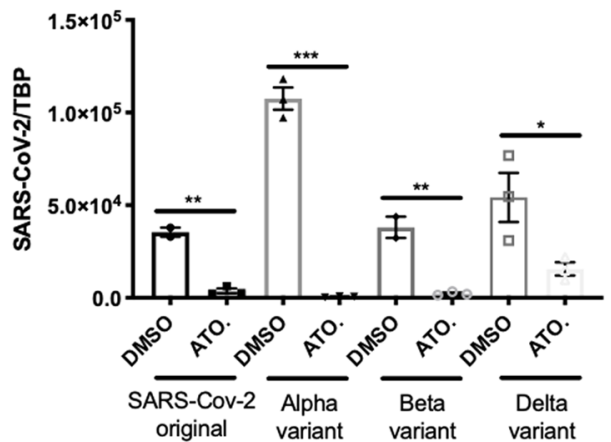

C
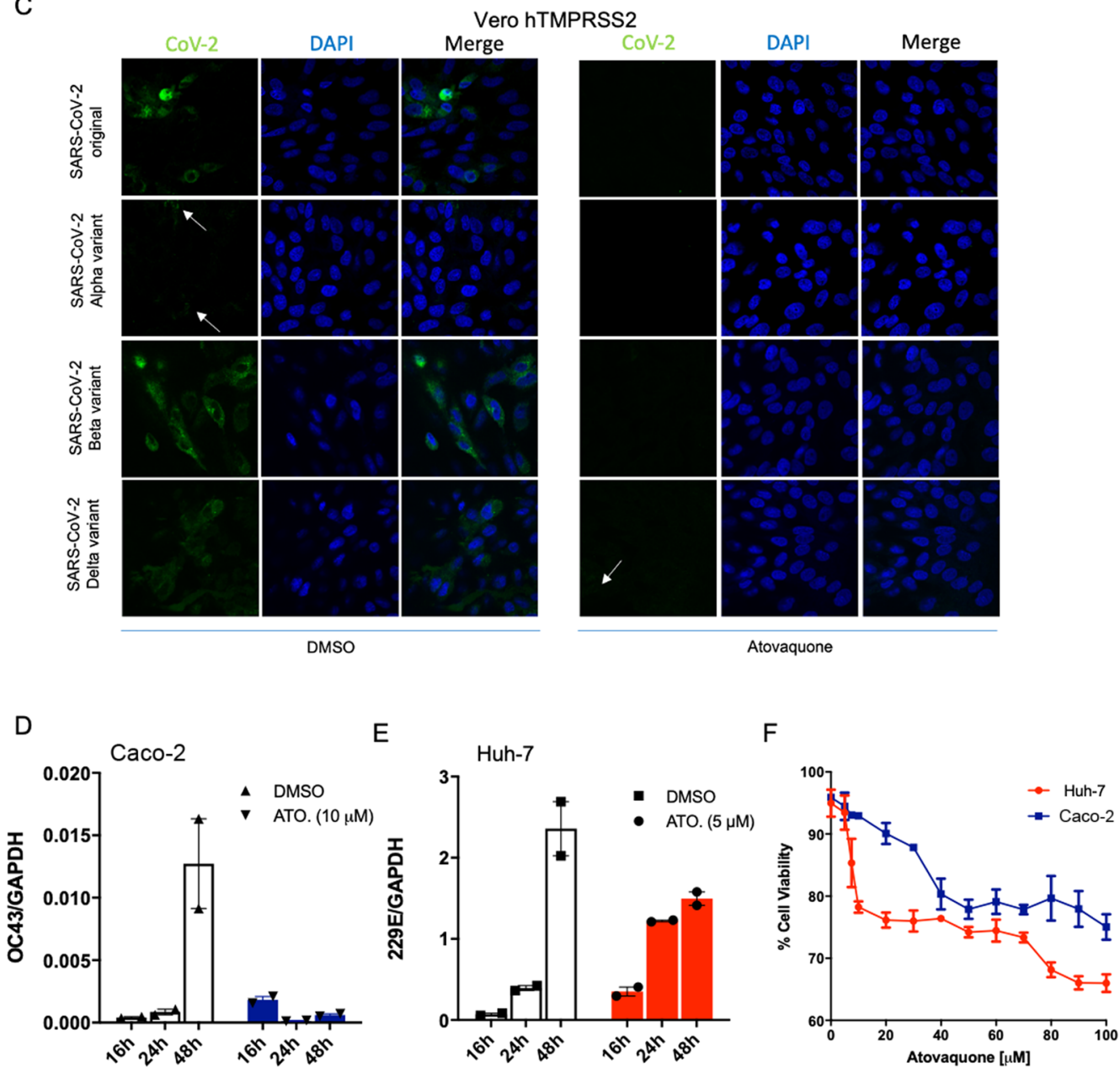

Figure 3. Atovaquone broadly inhibits coronavirus infectivity including different SARS-CoV-2 variants of concern in vitro. (A, B) VeroE6 hTMPRSS2 cells were pretreated with atovaquone $(10 \mu \mathrm{M})$ for $2 \mathrm{~h}$ before infection with the original SARS-CoV-2 or different variants of concern (cluster 5, alpha, beta, and delta variants) (MOI of 0.1). The viral RNA levels were determined $48 \mathrm{~h}$ postinfection by qPCR. In panel (A), the data represent the means \pm SEM of two independent experiments, while in panel (B), the data are representative of one experiment performed in triplicate. The experiment in (B) was repeated multiple times with a similar trend. (C) VeroE6 hTMPRSS2 cells were seeded on glass cover slips before $2 \mathrm{~h}$ of treatment with atovaquone $(10 \mu \mathrm{M})$ and subsequent infection with SARS-CoV-2 and other variants of concern (MOI of 0.1$)$. The spike protein was visualized by immunostaining and confocal imaging. Nuclei were stained using DAPI. The experiment was repeated twice. (D, E) Caco-2 and Huh-7 cells were pretreated for $2 \mathrm{~h}$ with atovaquone at the indicated concentrations and then infected with OC43 and $229 \mathrm{E}$ coronaviruses, respectively. The viral RNA was quantified at 16,24 , and $48 \mathrm{~h}$ postinfection and normalized to GAPDH. The bars indicate the means \pm SEM from two independent experiments. (F) Huh-7 (red line) and Caco-2 (blue line) cells were treated with atovaquone at the indicated concentrations for $48 \mathrm{~h}$ and then stained with 7-AAD to measure the cell viability by flow cytometry. All data shown represent the means \pm SD from two independent experiments. The $p$ values were calculated using a $t$-test where $* p<0.05, * * p<0.01, * * * p 0.001$.

could be at play in the atovaquone antiviral activity, VeroE6 hTMPRSS2 cells were pretreated with the glycolysis inhibitor, 2-doxy-glucose (2-DG), before atovaquone treatment and virus infection. Although 2-DG treatment prevented the shift 
A
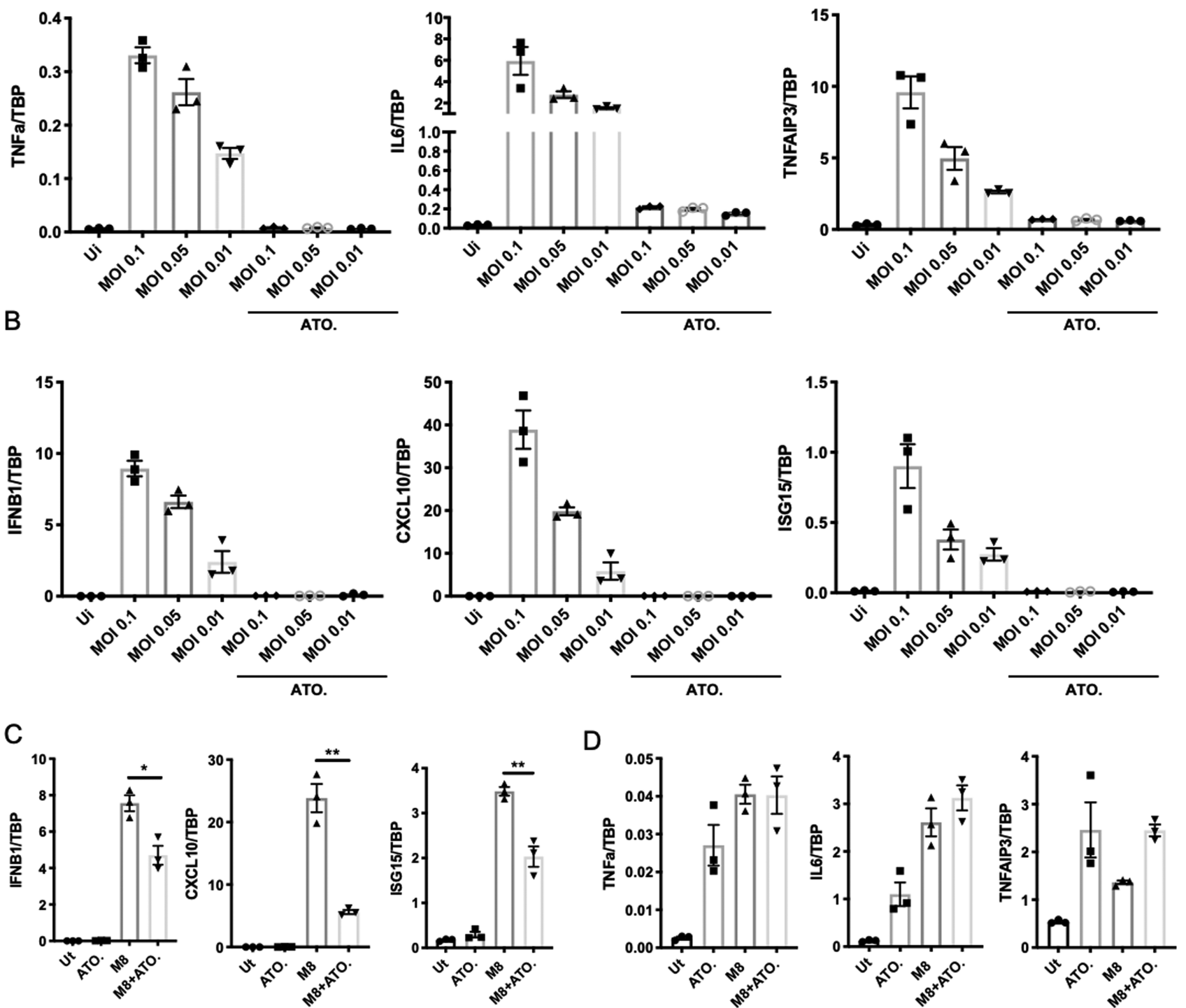

E

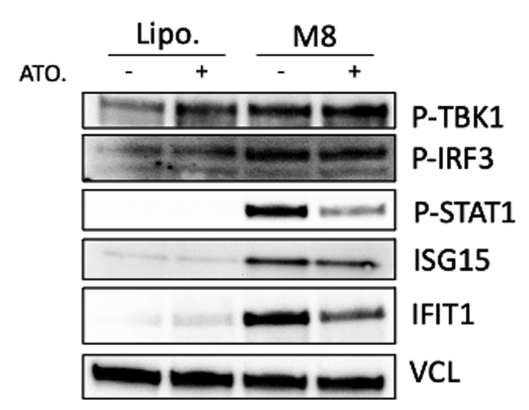

$\mathrm{F}$

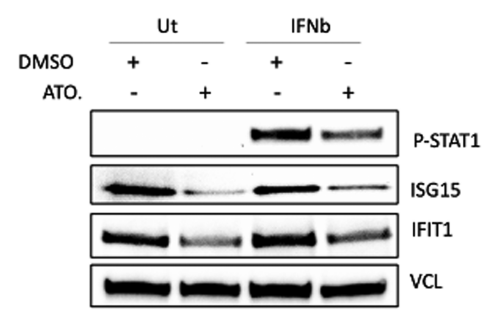

Figure 4. Atovaquone limits SARS-CoV-2 and synthetic RNA ligand-induced inflammatory responses. (A, B) Calu-3 cells were pretreated for 2 h with atovaquone $(100 \mu \mathrm{M})$. The cells were subsequently infected with SARS-CoV-2 (increasing MOIs) for $48 \mathrm{~h}$. The RNA levels of inflammatory (A) and antiviral (B) genes were quantified by qPCR. Data are the means \pm SEM from one experiment performed in biological triplicates. Experiments were repeated twice with similar findings. (C, D) Calu-3 cells were pretreated for $2 \mathrm{~h}$ with atovaquone (100 $\mu \mathrm{M})$ and subsequently transfected using lipofectamine with a sequence-optimized RIG-I agonist (M8) $(3.5 \mathrm{ng} / \mathrm{mL})$ for $6 \mathrm{~h}$. The antiviral (C) and inflammatory (D) gene expression levels were assessed by qPCR. Data are the means \pm SEM from one experiment performed in biological triplicates. (E, F) Calu-3 cells were pretreated for $2 \mathrm{~h}$ with atovaquone $(100 \mu \mathrm{M})$ and subsequently lipofected with a sequence-optimized RIG-I agonist (M8) (3.5 ng/mL) for 3 $\mathrm{h}(\mathrm{E})$ or stimulated with IFNb1 $(1000 \mathrm{IU} / \mathrm{mL})$ for $1 \mathrm{~h}(\mathrm{~F})$. Activation of the antiviral response was assessed by immunoblotting. The $p$ values were calculated using a $t$-test where $* p<0.05, * * p<0.01, * * * p<0.001$. 
A

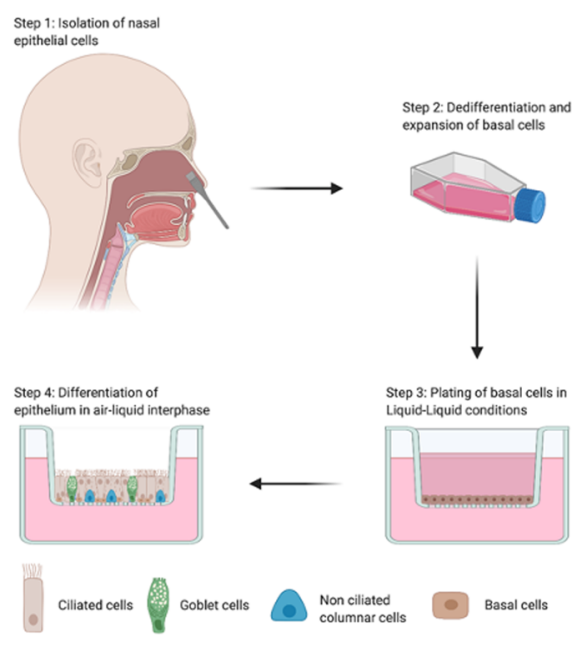

B

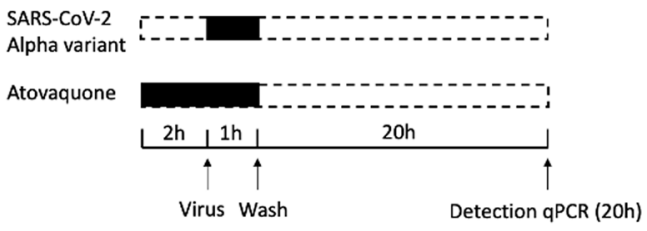

C

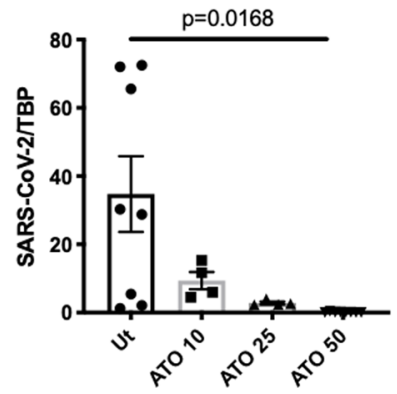

Figure 5. Atovaquone restricts SARS-CoV-2 infection in a primary human airway model. (A) Schematic representation of the collection and processing of the cells for the development of the primary human airway epithelium model. (B) Schematic of atovaquone administration and virus infection. (C) Human airway epithelia were pretreated for $2 \mathrm{~h}$ with increasing doses of atovaquone before infection with SARS-CoV-2 (alpha variant) (MOI of 0.1 ) for $1 \mathrm{~h}$. The infected media were washed away and further replaced by clean complete media. Viral RNA levels were determined $20 \mathrm{~h}$ postinfection by qPCR. Data are the means from two independent experiments performed for two independent donors in biological duplicates for UT and ATO. $50 \mu \mathrm{M}$ conditions. The data for atovaquone 10 and $25 \mu \mathrm{M}$ conditions are from two independent experiments carried out for one donor in biological duplicates. The $p$ value was determined using a paired $t$-test.

toward glycolysis and restored the neutral $\mathrm{pH}$ levels, as observed in Figure S5B, the atovaquone antiviral activity was fully retained and even further enhanced in the absence of glycolysis (Figure S5C). Atovaquone has also been reported to alter the pyrimidine and purine biosynthesis pathways. ${ }^{12-15}$ To test whether inhibition of pyrimidine or purine biosynthesis could be involved in some of the intracellular antiviral action of atovaquone, VeroE6 cells expressing hTMPRSS2 were infected following treatment with atovaquone and replenishment of the culture media with uridine $(\mathrm{U})$, cytidine $(\mathrm{C})$, adenosine $(\mathrm{A})$, and guanosine $(G)$. Here again, the antiviral activity of atovaquone was fully retained independent of the different culture conditions (Figure S5D). Altogether, these data highlight that atovaquone likely possesses a complex mode of action against SARS-CoV-2, both working pre- and postinfection. Based on the evidence presented, we suggest a possible use of the drug for treatment of COVID-19 prophylactically but also potentially following exposure to the virus.

\section{DISCUSSION}

This study demonstrates that the antimicrobial drug atovaquone inhibits SARS-CoV-2 infection and replication in vitro as well as prevents the expression of associated inflammatory markers in human lung infected cells. Mechanistically, we show that atovaquone may interfere with the binding of the spike protein and the human receptor ACE2 during the entry phase. We also demonstrate a probable partial requirement for TMPRSS 2 in driving the antiviral effect of the drug. Finally, our experiments also suggest an intracellular action of the drug on virus replication through a mechanism yet to be determined but not involving mitochondrial dysfunction and inhibition of the purine or pyrimidine biosynthesis pathways. Importantly, atovaquone is an FDAapproved, well-tolerated, and orally available drug currently in use for the treatment of different infectious diseases. Together with the anecdotal observations of the possible beneficial effects of the drug in Canadian patients, combined with our in vitro data on its antiviral activity against several variants of concern and in the primary lung epithelium cell culture model, the findings presented here suggest that atovaquone could provide benefits and may easily be repurposed. We are now awaiting the results from the clinical trials initiated in the USA where atovaquone was administered alone or in combination with azithromycin to confirm whether this medication is a good candidate as an inhibitor of SARS-CoV-2 replication and inflammation-induced pathology in COVID-19 patients.

Since the emergence of SARS-CoV-2 and the beginning of the global pandemic in December 2019, tremendous scientific and technological advances have been made in developing safe and efficacious vaccine candidates. ${ }^{1-4}$ However, challenges in vaccine distribution and availability as well as the emergence of new variants could mean that reaching the necessary levels of immunity to suppress SARS-CoV-2 will still take a considerable amount of time. This further highlights the important need for the continued research and development of antivirals, which can protect individuals from developing severe COVID-19, in the absence of immunization. Furthermore, high-fatality coronavirus outbreaks have now been reported roughly every 10 years since the identification of SARS in China in 2002 followed by the MERS epidemic in Saudi Arabia in 2012. Given the zoonotic nature of these viral outbreaks, a future coronavirus pandemic is extremely likely, and therefore, developing broadly acting antivirals or repurposing already clinically approved drugs against coronaviruses should be of the highest priority for public health.

Our study focused on uncovering the potential antiviral effect of atovaquone in vitro. In cellular models of infection, our experiments showed promising and significant dosedependent block in the infectivity of replicative wtVSV and VSV-spike in different types of VeroE6 cells expressing hACE2 and/or hTMPRSS2. Furthermore, we confirmed that the 


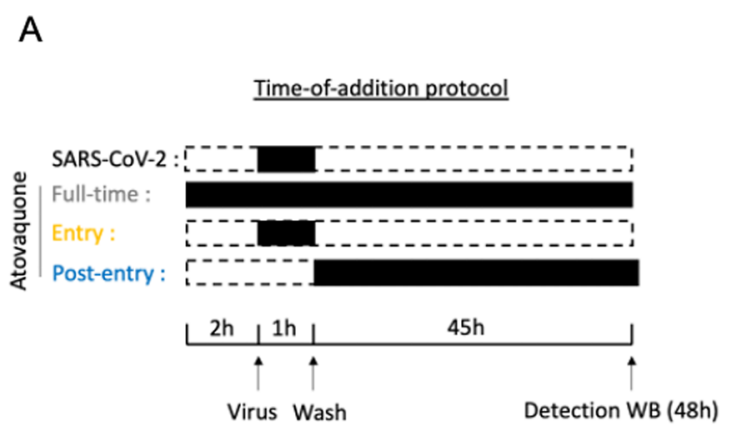

\section{B}
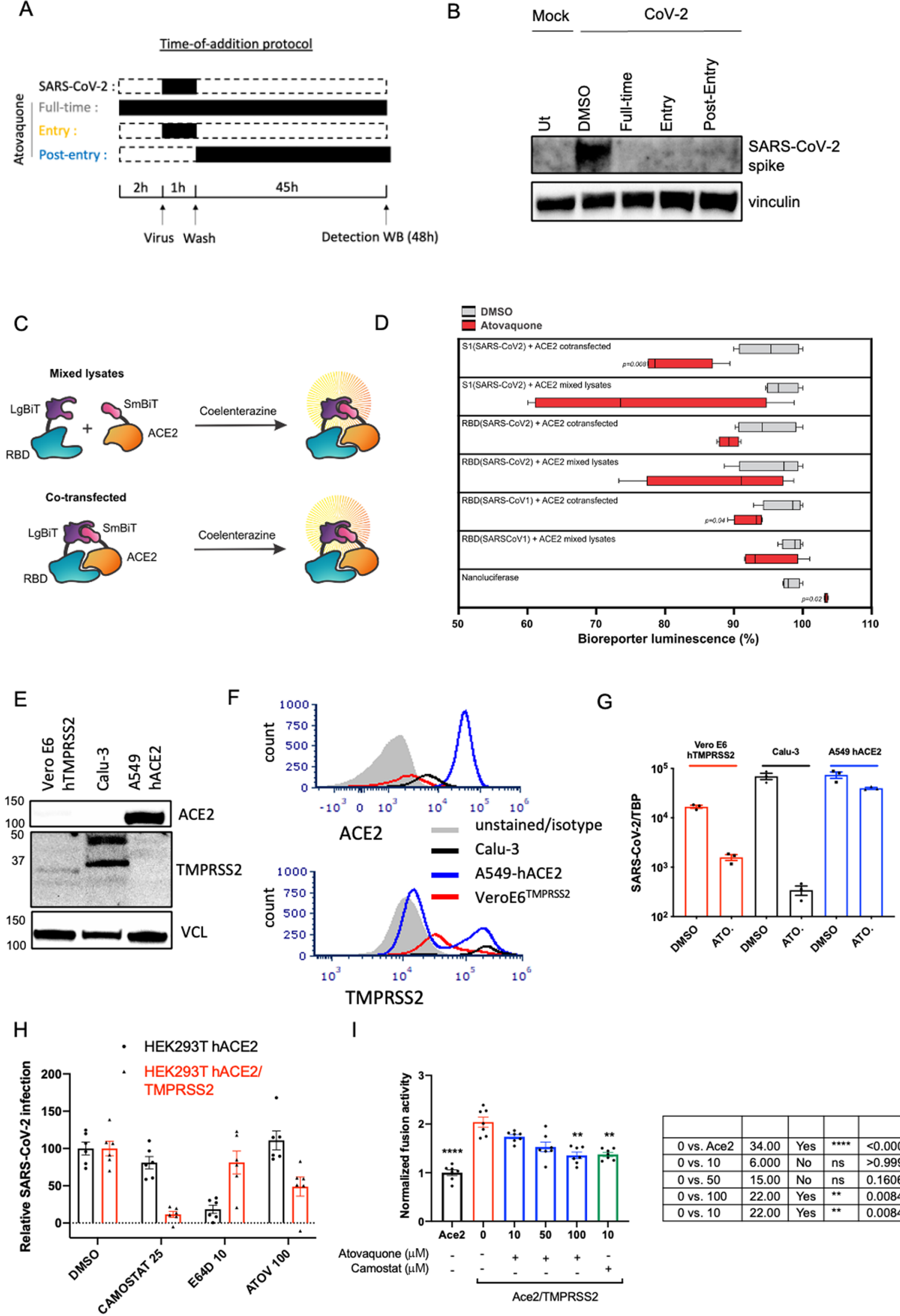

I

G
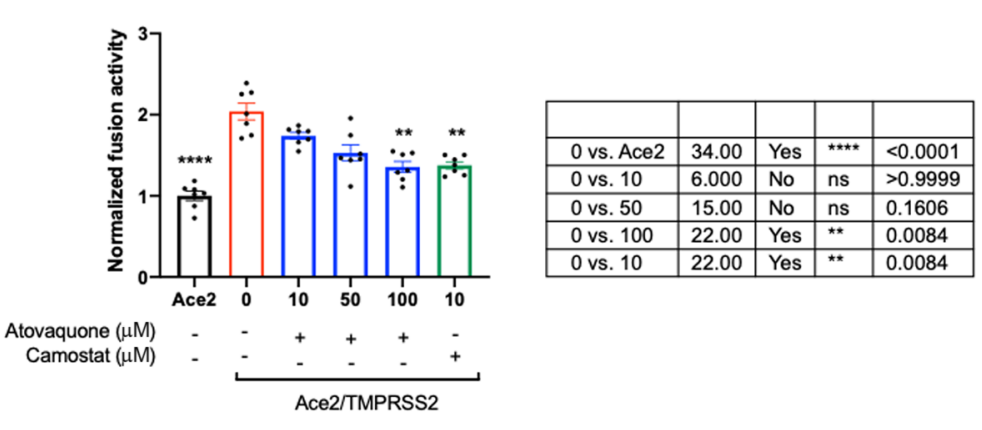

Figure 6. Atovaquone partially requires TMPRSS2 to drive its antiviral action against SARS-CoV-2 and reduces the interaction between the spike protein and its surface receptor ACE2. (A) Schematic of atovaquone administration. (B) VeroE6 hTMPRSS2 cells were treated with atovaquone $(10 \mu \mathrm{M})$ for $2 \mathrm{~h}$ before infection (full time), at the time of infection (entry), or $1 \mathrm{~h}$ after infection (postentry), before challenging with original SARS-CoV-2 at an MOI of 0.1. Infection was carried out for $48 \mathrm{~h}$ in the presence of the drug and for all conditions. Infection was assessed by immunoblotting of the spike protein within cell lysates. (C) Structure of constructs for a split NanoLuc-based bioreporter. RBD or S1 from either 
Figure 6. continued

SARS-CoV1 or SARS-CoV2 was linked to Large BiT (LgBiT) on its N-terminus to form LgBiT-RBD or LgBiT-S1; similarly, the Small BiT (SmBiT) peptide was linked to human ACE2 to form SmBiT-ACE2. ACE2 and RBD or S1 constructs were transfected separately or cotransfected into HEK293 cells for $48 \mathrm{~h}$ and lysed with a passive lysis buffer. Mixed lysates or lysates from cotransfected cells were incubated with coelenterazine, and the luminescence measured using a plate reader. (D) Following plasmid transfection into HEK293 cells, the cells were lysed in a NanoLuc-compatible passive lysis buffer and lysates were dispensed into a 96-well plate, to which atovaquone was added at a final concentration of $4 \mu \mathrm{M}$. The impact of atovaquone on SARS receptor binding was assessed in two ways: (1) with atovaquone added to LgBiT-RBD or LgBiT-S1 for $50 \mathrm{~min}$ followed by the addition of an equal quantity of SmBiT-ACE2 for another $10 \mathrm{~min}$ ("mixed lysates)" or (2) with atovaquone added to the preformed SmBiT-ACE2 + LgBiT-RBD/S1 complex for $1 \mathrm{~h}$ ("cotransfected)." Following incubation, a nanoluciferase substrate was added and the luminescence was measured. HEK293 cells were also transfected with a nanoluciferase control plasmid and lysates were incubated with $4 \mu \mathrm{M}$ atovaquone. $N=4$ per condition. The graph shows \% bioreporter luminescence with the highest value in each of the respective untreated conditions taken as $100 \%(N=4$ per condition, the $p$ values were determined using a $t$-test $)$. (E, F). The different cell lines mentioned were subjected to immunoblotting (E) and flow cytometry analysis (F) of TMPRSS2 and ACE2 expression. For ACE2, unstained samples of the matched cell line were used as a control. For TMPRSS2, secondary antibody-stained samples of the matched cell line were used as a control. Controls for the A549 hACE2 cell line are represented in the figure. The same controls were used for all cell lines studied. (G) Vero hTMPRSS2, Calu-3, and A549 hACE2 cells were pretreated with atovaquone $(100 \mu \mathrm{M})$ for $2 \mathrm{~h}$ before infection with the original SARS-CoV-2 (MOI of 0.1 ). Viral RNA levels were determined $48 \mathrm{~h}$ postinfection by qPCR. The data represent the means \pm SEM of one experiment performed in biological triplicates. (H) HEK293T cells expressing hACE2 cells were mock-transfected or transfected with a plasmid encoding hTMPRSS2. Twenty-four hours post-transfection, cells were seeded in 96-well plates and preincubated with the different drugs E64d (10 $\mu \mathrm{M})$, camostat $(25 \mu \mathrm{M})$, and atovaquone $(100 \mu \mathrm{M})+5 \mu \mathrm{g} / \mathrm{mL}$ polybrene for $1 \mathrm{~h}$ before infection with purified SARS-CoV-2 pseudotypes. LacZ + cells were quantified using the Beta-Glo assay system and luminescence measurement. The data are the means \pm SEM of two experiments performed in biological triplicates. Similar results were obtained by X-gal staining. (I) Effector cells (zipV2+) expressing SARS-CoV-2 spike and target cells (zipV1+) expressing ACE2 with or without TMPRSS2 were cocultured for $3 \mathrm{~h}$ in the presence of the indicated concentration of drugs or DMSO. Cell-cell fusion was assessed by measuring the fluorescence of the Venus protein complementation (zipV1 + zipV2). Data were normalized to the fusion obtained with target cells expressing ACE2 but not TMPRSS2 (ACE2 + TMPRSS2) and are the means \pm SEM of two experiments performed in triplicates. The $p$ values were calculated using a $t$-test where $*_{p}<0.05, * * p<0.01, * * * p<0.001$.

antiviral action of atovaquone was retained against both the ancestral SARS-CoV-2 and other variants of concern in similar cellular testing systems. However, a recent study from Dittmar et al. highlighted the importance of validating drug candidates in relevant human lung epithelial cells. Their study identified major differences in drug sensitivity and entry pathways used by SARS-CoV-2 in different cell types. For instance, entry in lung epithelial Calu-3 cells was shown to be $\mathrm{pH}$-independent and required TMPRSS2, while entry in Vero and Huh7.5 cells required low $\mathrm{pH}$ and was rather triggered by acid-dependent endosomal proteases. ${ }^{28}$ Thus, we extended our studies to lung epithelial Calu-3 cells and found that atovaquone still displayed high antiviral activity against SARS-CoV-2 without affecting the cellular viability in this particularly relevant in vitro system. Even more importantly, the antiviral action of atovaquone was fully retained against the SARS-CoV-2 alpha variant in the primary human airway lung epithelium culture model.

One study which employed large-scale screening of FDAapproved drugs to identify promising SARS-CoV-2 antivirals identified quinones as useful agents to inhibit infectious SARSCoV-2 production. ${ }^{29}$ In addition, a current preprint described atovaquone as a particularly promising agent due to its covalent binding to the SARS-CoV-2 main protease enzyme $\left(\mathrm{M}^{\mathrm{pro}}\right)$, which suggests that the antiviral effects are durable. ${ }^{23}$ Our study identified atovaquone as a drug with a possible multimodal action on the virus, which can act both prophylactically and therapeutically in vitro; mechanistically, we report a modest but significant reduction in the binding between the spike S1 domain and ACE2 and demonstrate a dependency on TMPRSS2 in driving atovaquone-mediated antiviral effects against SARS-CoV-2. Additionally, atovaquone slightly impaired the fusion process as measured experimentally in an in vitro assay. Previous studies reported that TMPRSS2 can also cleave the ACE2 receptor and thus limit its surface expression. ${ }^{30}$ Although atovaquone was unable to inhibit the TMPRSS2 activity in an in vitro assay using a peptide substrate, it is unknown whether similar results would be obtained with other substrates such as ACE2. Therefore, it would be pertinent to assess in future studies whether the atovaquone-induced antiviral activity could result from cleavage of ACE2 through the TMPRSS2-mediated proteolytic activity.

Altogether our data provide some hints as to how the drug affects the entry step of the virus. We also show that atovaquone can act at the postentry step and affect the intracellular phase of viral replication through a modality of action yet to be determined but not involving the alteration of the mitochondrial function or the synthesis of purine or pyrimidines by the molecule.

Altogether, our study reports atovaquone as a potent in vitro antiviral agent against SARS-CoV-2 and highlights that results from future efficacy studies in clinical trials in humans are needed to determine whether the drugs identified here could be used alone or in combination as a treatment for COVID-19.

\section{METHODS}

Reagents. Atovaquone (Sigma-Aldrich, Saint Louis, MO, USA) was dissolved in dimethyl sulfoxide (DMSO) at a concentration of 10 or $27 \mathrm{mM}$ and then stored at $-20{ }^{\circ} \mathrm{C}$ until use. Camostat mesylate (Cayman Chemical) and E64d (Millipore Sigma) were dissolved in DMSO at $10 \mathrm{mM}$ and stored at $-20{ }^{\circ} \mathrm{C}$ until use. On the day of treatment, the drugs were predissolved in a complete culture medium containing fetal bovine serum (FBS), Pen/Strep, and glutamine to a $10 \times$ solution. Final dilutions to the expected concentrations were carried out in the culture well also containing the complete medium. Of note, atovaquone had a tendency to form large aggregates if not resuspended in culture medium containing FBS, Pen/Strep, and glutamine.

Cell Lines. Calu-3 epithelial lung cancer cells (kindly provided by Laureano de le Vega, Dundee University, Scotland, UK) and human lung adenocarcinoma epithelial A549 cells expressing hACE2 (kindly provided by Brad Rosenberg, Icahn School of Medicine at Mount Sinai, New 
York, USA) were grown as a monolayer in DMEM10 (Dulbecco's modified Eagle's medium, DMEM, Life Technologies), supplemented with $10 \%(\mathrm{v} / \mathrm{v})$ high fetal calf serum (hiFCS), $2 \mathrm{mM}$ L-glutamine, $100 \mathrm{U} / \mathrm{mL}$ penicillin, and 100 $\mu \mathrm{g} / \mathrm{mL}$ streptomycin. VeroE6 cells expressing TMPRSS2 (VeroE6-hTMPRSS2, kindly provided by Professor Stefan Pöhlmann, University of Göttingen $)^{28}$ were grown in DMEM5 (DMEM supplemented with 5\% (v/v) hiFCS, $2 \mathrm{mM} \mathrm{L-}$ glutamine, $100 \mathrm{U} / \mathrm{mL}$ penicillin, and $100 \mu \mathrm{g} / \mathrm{mL}$ streptomycin), supplemented with $10 \mu \mathrm{g} / \mathrm{mL}$ blasticidin (InvivoGen) to maintain TMPRSS2 expression. HEK293T cells (American Type Culture Collection, ATCC) and HEK293T-hACE2 cells (kind gift of Dr. Hyeryun Choe, Scripps Research) were cultured in DMEM supplemented with 10\% FBS (Sigma), 100 $\mathrm{U} / \mathrm{mL}$ penicillin, $100 \mu \mathrm{g} / \mathrm{mL}$ streptomycin, and $0.3 \mathrm{mg} / \mathrm{mL} \mathrm{L-}$ glutamine. Human colorectal adenocarcinoma Caco-2 cells, kindly provided by Prof. Maria Teresa Fiorenza (Sapienza University, Rome, Italy), and hepatocyte-derived cellular carcinoma Huh-7 cells were cultured in DMEM high glucose with sodium pyruvate (Euroclone) supplemented with $10 \%$ heat-inactivated FBS, $100 \mathrm{U} / \mathrm{mL}$ penicillin, $100 \mu \mathrm{g} / \mathrm{mL}$ streptomycin, and $300 \mu \mathrm{g} / \mathrm{mL}$ glutamine (complete DMEM). For the fusion assay, human embryonic kidney 293T (HEK293T) cells were obtained from ATCC (CRL11268 ) and maintained in complete media (DMEM supplemented with 5\% FBS (Fisher Scientific), 5\% bovine calf serum (Fisher Scientific), and $1 \times$ antibiotic-antimycotic (Fisher Scientific)). All cell lines were cultured at $37^{\circ} \mathrm{C}$ and $5 \% \mathrm{CO}_{2}$.

HAE Culture. The HAE model was generated as previously described in ref. ${ }^{31}$ Experiments were performed on two individual donors, each condition being present in biological duplicates.

Viral Strains and SARS-CoV-2 Propagation. The Wuhan-like early European SARS-CoV-2 B.1 lineage (FR4286) was kindly provided by Professor Georg Kochs (University of Freiburg), Professor Arvind Patel (University of Glasgow, UK) kindly provided the alpha variant B.1.1.7, and the beta variant B.1.351 was kindly provided by Professor Alex Sigal, African Health Research Institute, South Africa. SARSCoV-2 cluster 5 (mink variant) (SARS-CoV-2/hu/DK/CL-5/ 1) and delta variant B.1.617.2 (SARS-CoV2/hu/DK/SSI-H11) were provided by Statens Serum Institut, SSI, Denmark. B.1 (FR-4286), alpha, delta, and cluster-5 variants were propagated using VeroE6-hTMPRSS2, while the beta variant was propagated in human A549-hACE2. In brief, $20 \times 10^{6}$ cells were seeded in different T175 culture flasks and infected the following day at 0.005 multiplicity of infection (MOI) in $8 \mathrm{~mL}$ of a serum-free medium. One hour after infection, the culture medium was increased with an extra $10 \mathrm{~mL}$ of medium containing serum, and virus propagation was continued until $72 \mathrm{~h}$ post infection. To isolate the virus, cell culture supernatants were removed from the different flasks, centrifuged at $300 \times g$ for $5 \mathrm{~min}$ to remove the cell debris, and viruses were concentrated in Amicon filter tubes by spinning at $4000 \times g$ for $30 \mathrm{~min}$. The concentrated virus was further aliquoted and stored at $-80{ }^{\circ} \mathrm{C}$. The amount of infectious virus in the generated stock was determined using a limiting dilution assay (TCID50). hCoV-229E (ATCC VR740) was grown and maintained in Huh-7 cells. hCoV-OC43, kind gift from Prof. Carolina Scagnolari (Sapienza University, Rome, Italy), was grown and maintained in Caco-2 cells.
SARS-CoV-2 Infection Experiments. VeroE6 TMPRSS2 cells, A549 cells expressing the human ACE2 receptor, and wild-type VeroE6 cells were seeded as $1.5 \times 10^{5}$ cells per well, while Calu-3 cells were seeded as $2 \times 10^{5}$ cells per well in complete DMEM in a 24-well plate. The following day, cells were pretreated with different concentrations of atovaquone for $2 \mathrm{~h}$, prior to viral infection. SARS-CoV-2 (the original Freiburg strain or the different variants of concern, namely, cluster 5, alpha, beta, and delta variants) was added as an MOI of 0.1 for $1 \mathrm{~h}$ in the presence of the drug. For Calu-3, different MOIs of the SARS-CoV-2 Freiburg strain were also tested (MOIs of $0.1,0.05$, and 0.01 ). After $1 \mathrm{~h}$, the virus-containing medium was removed and replaced with a fresh complete DMEM medium containing atovaquone for $48 \mathrm{~h}$. Cells were then rinsed in phosphate-buffered saline (PBS) and lysed in $400 \mu \mathrm{L}$ of lysis buffer (Roche, 11828665001) followed by RNA extraction and gene expression analysis. For the experiments investigating the mode of action of atovaquone, the drug treatment was added full time, as described above, during pretreatment only (entry), or only postinfection (postentry).

229E and OC43 Coronavirus Infections. Huh-7 and Caco- 2 cells were seeded in 24 -well plates at $1.2 \times 10^{5}$ cells/ well overnight at $37^{\circ} \mathrm{C}$ in complete DMEM. The day after the cells were pretreated with atovaquone (5 and $10 \mu \mathrm{M}$, respectively) for $2 \mathrm{~h}$, using DMSO as a negative control, the cells were then infected with 229E and OC43 hCoVs for $1 \mathrm{~h}$ in serum-free DMEM, and after infection, the medium was replaced with complete DMEM containing atovaquone. At 16, 24 , and $48 \mathrm{~h}$ postinfection, cells were collected and lysed and the total RNA was extracted using an RNeasy mini kit (Qiagen) according to the manufacturer's instructions. RNA was reverse-transcribed using a PrimeScript RT reagent kit with gDNA Eraser (Takara) into cDNA, and qPCR was then performed using a TaqMan fast advanced master mix (Life Technologies) on a StepOnePlus real-time PCR system (Thermo Fisher Scientific). CT values were normalized to GAPDH $(\Delta \mathrm{CT})$. The primers used were as follows: for 229E, forward primer: ACCAACATTGGCATAAACAG, reverse primer: CGTTGACTTCAAACCTCAGA, probe: FAM-AGTTAAAGCACTTGCCACCGCC-TAM; for OC43, forward primer: AGCAGACCTTCCTGAGCCTTCAAT, reverse primer: AGCAACCAGGCTGATGTCAATACC, probe: FAMTGACATTGTCGATCGGGACCCAAGTA-TAM. The differential mRNA expression of genes in the samples was expressed as $2^{-\Delta \mathrm{CT}}$.

Nanoluciferase Complementation-Based Biosensor Assay. The nanoluciferase complementation assay has been previously described in refs. ${ }^{24,25}$ We tested the impact of atovaquone on SARS binding to ACE2 using a variety of plasmid constructs, notably the $\mathrm{RBD}$ or $\mathrm{S} 1$ domain from SARS-CoV2 or the RBD domain from SARS-CoV1 as described. $^{24,25}$ Following plasmid transfection using a PolyJet transfection reagent (SignaGen Laboratories) in HEK293, cells were lysed in a NanoLuc-compatible passive lysis buffer (Promega) and the lysate was dispensed into a 384-well plate to which atovaquone was added at a final concentration of 4 $\mu \mathrm{M}$. The impact of atovaquone on SARS receptor binding was assessed in two ways: (1) with atovaquone added to SmBiTACE2 for 50 min followed by the addition of an equal quantity of LgBiT-RBD or LgBiT-S1 for another $10 \mathrm{~min}$ ("mixed lysates)" or (2) with atovaquone added to the preformed SmBiT-ACE2 + LgBiT-RBD/S1 complex for $1 \mathrm{~h}$ ("cotransfected)." Following incubation, nanoluciferase substrate-native 
coelenterazine (CTZ, $3.33 \mathrm{mM}$ final concentration, Nanolight Technologies-Prolume Ltd., Pinetop, AZ, USA) was added, and luminescence was measured using the Synergy microplate reader (BioTek, Winooski, VT, USA). HEK293 cells were also transfected with a nanoluciferase control plasmid and lysates were incubated with $4 \mu \mathrm{M}$ atovaquone.

SARS-CoV-2 Spike-Pseudotyped VSV and wtVSV Studies. pLenti CMV Hygro TMPRSS2 and pLenti CMV Puro ACE2 (a kind gift from Dr. A.C. Gingras, University of Toronto, Canada) were used to generate lentivirus via second generation pSPAX2 and pMD2.G (encoding VSV-G). VeroE6 cells (ATCC, CRL-1586) were cotransduced with ACE2 and TMPRSS2 lentivirus to generate Vero hACE2-hTMPRSS2 and selected with $3 \mu \mathrm{g} / \mathrm{mL}$ puromycin and $200 \mu \mathrm{g} / \mathrm{mL}$ hygromycin.

VSV encoding the SARS-CoV-2 S protein in the place of the native envelope spike glycoprotein (VSV-eGFP-spike) was obtained from Dr. S.P.J. Whelan. wtVSV (Indiana serotype) expressing eGFP and wtVSV-eGFP-spike viruses were propagated on Vero76 or VeroE6 cells in roller bottles. wtVSV was purified using a 5-50\% OptiPrep (Sigma) gradient, and all virus titers were quantified by a standard plaque assay on Vero76 or VeroE6 cells.

For evaluation of the antiviral potential of atovaquone, VeroE6 cells or Vero hACE2-hTMPRSS2 were seeded at $2.5 \times$ $10^{4}$ cells $/ \mathrm{cm}^{2}$ in 96-well plates and treated with various concentrations of atovaquone using the Agilent Bravo liquid handler. Fifteen minutes later, cells were infected at an MOI of 1 with wtVSV-spike or wtVSV expressing green fluorescent protein (GFP). Eleven hours postinfection, cells were imaged and GFP counts were obtained using the ArrayScan High Content Platform (Thermo Scientific Cellomics). Forty-eight hours postinfection, the viability was determined using resazurin sodium salt (Sigma-Aldrich).

Limiting Dilution Assay (TCID50 Assay). To determine the amount of infectious virus in the cell culture supernatant or generated virus stocks, a limiting dilution assay was performed. A total of $2 \times 10^{4}$ VeroE6-TMPRRS2 cells was seeded in 90 $\mu \mathrm{L}$ of DMEM with $2 \%$ FBS in 96-well plates. The following day, samples were thawed and $10 \times$ diluted followed by 10 -fold serial dilution using DMEM with $2 \% \mathrm{FBS}$, and $10 \mu \mathrm{L}$ of each dilution was added to the cells. The final dilution range was $10^{-2}-10^{-12}$ in octuplicates. Each well was evaluated for cytopathic effect (CPE) by eye using standard microscopy, and the tissue culture infectious dose $50 \quad\left(\mathrm{TCID}_{50} / \mathrm{mL}\right)$ was calculated using the Reed and Muench method. ${ }^{32}$ To convert to the mean number of plaque forming units $(\mathrm{pfu}) / \mathrm{mL}$, the $\mathrm{TCID}_{50} / \mathrm{mL}$ value was multiplied by a factor of 0.7 (ATCC converting TCID [50] to plaque forming units (PFU)). Additionally, cells were fixed by adding $10 \%$ formalin (SigmaAldrich) at a 1:1 (v/v) ratio, stained with a crystal violet solution (Sigma-Aldrich) and stored at room temperature.

qPCR. The gene expression was determined by real-time qPCR, using TaqMan detection systems (Applied Biosciences). RNA was extracted using the high pure RNA isolation kit (Roche, 11828665001) according to the manufacturer's instructions with RNA being eluted in $60 \mu \mathrm{L}$ of sterile RNAse-free water. The RNA quality and purity were further assessed by Nanodrop spectrometry (DeNovix DS-11). RNA levels were analyzed using premade TaqMan assays and the RNA-to-Ct-1-Step kit according to the manufacturer's recommendations (Applied Biosciences). We used the commercially available TaqMan assay (Thermo Fischer
Scientific, cat. no. 4392938), and samples were analyzed in a $10 \mu \mathrm{L}$ (final volume) reaction mix containing $5 \mu \mathrm{L}$ of master mix, $0.2 \mu \mathrm{L}$ of RT enzyme, $3.64 \mu \mathrm{L}$ of nuclease-free water, 0.16 $\mu \mathrm{L}$ of primers (TBP, ACTB, TNFa, IL6, IFNB1, CXCL10, and ISG15, all obtained from Thermo Fisher), and $1 \mu \mathrm{L}$ of either pure or diluted RNA as mentioned. For the SARS-CoV-2 gene, primers and probe sequences were provided by the CDC and purchased from Eurofins. Samples were analyzed in a final volume of $10 \mu \mathrm{L}$, containing $5 \mu \mathrm{L}$ of master mix, $0.5 \mu \mathrm{L}$ of fw primer $(10 \mathrm{pmol} / \mu \mathrm{L}$ fw primer-AAATTTTGGGGACCAGGAAC), $0.7 \mu \mathrm{L}$ of rev primer (10 pmol $/ \mu \mathrm{L}$ rev primerTGGCACCTGTGTAGGTCAAC), $0.2 \mu \mathrm{L}$ of probe (20 $\mathrm{pmol} / \mu \mathrm{L}-\mathrm{FAM}$-ATGTCGCGCATTGGCATGGA-BHQ), $2.4 \mu \mathrm{L}$ of nuclease-free water, and $1 \mu \mathrm{L}$ of RNA diluted or not. The analysis was performed on a Applied Biosciences qPCR platform with program: $2^{\prime} 50{ }^{\circ} \mathrm{C} ; 2^{\prime} 95{ }^{\circ} \mathrm{C}$; $40 \times\left(1{ }^{\prime \prime} 95{ }^{\circ} \mathrm{C}\right.$; $\left.20^{\prime \prime} 60{ }^{\circ} \mathrm{C}\right)$. CT values were extracted using Applied Biosciences Software.

Confocal Microscopy. VeroE6 cells expressing human TMPRSS2 or Calu-3 cells were seeded onto glass cover slips placed on the bottom of 12-well plates and treated with either DMSO $(0.1 \%)$ or atovaquone $(10$ or $100 \mu \mathrm{M}$, respectively) for $2 \mathrm{~h}$ prior to challenging with SARS-CoV-2 (MOI of 0.1). After $48 \mathrm{~h}$, the cells were washed with Dulbecco's phosphatebuffered saline (DPBS) and fixed for $40 \mathrm{~min}$ in $4 \%$ paraformaldehyde (PFA), following 20-min permeabilization with $0.2 \%$ Triton X-100 in DPBS. Next, blocking with $2 \%$ FCS in DPBS was performed for $40 \mathrm{~min}$ and a mouse SARS-CoV-2 spike antibody (1:200, GeneTex) and a rabbit cleaved caspase3 antibody (1:400, Cell Signaling) were applied for $1 \mathrm{~h}$ at room temperature in the blocking solution. After three washes with DPBS, cells were incubated with a goat antirabbit Alexa Fluor $488 \mathrm{~nm}$ fluorophore-conjugated secondary antibody (1:400, Invitrogen), a goat antimouse Alexa Fluor $555 \mathrm{~nm}$ fluorophoreconjugated secondary antibody (1:400, Invitrogen), Alexa Fluor Plus 647 Phalloidin (1:400, Invitrogen), and PureBlu DAPI nuclear staining dye (1:100, Bio-Rad) for $1 \mathrm{~h}$ at room temperature in the dark. Cells were then washed three times with DPBS and mounted onto microscope slides using a ProLong gold antifade mounting medium (Invitrogen). Slides were air-dried in the dark and examined on the next day using a Zeiss LSM 710 inverted confocal microscope with corresponding Zeiss ZEN software.

Western Blotting. Immunoblotting was performed as previously described in ref. ${ }^{33}$ In brief, cells were lysed in 100 $\mu \mathrm{L}$ of ice-cold Pierce RIPA lysis buffer (Thermo Scientific) supplemented with $10 \mathrm{mM} \mathrm{NaF}, 1 \times$ complete protease cocktail inhibitor (Roche), and $5 \mathrm{IU} \mathrm{mL}^{-1}$ benzonaze (Sigma), respectively. The protein concentration was determined using a BCA protein assay kit (Thermo Scientific). Whole-cell lysates were denatured for $3 \mathrm{~min}$ at $95{ }^{\circ} \mathrm{C}$ in the presence of $1 \times \mathrm{XT}$ sample buffer (Bio-Rad) and $1 \times \mathrm{XT}$ reducing agent (Bio-Rad). A total of $30 \mu \mathrm{g}$ of reduced samples was separated by SDS-PAGE on 4-20\% Criterion TGX precast gradient gels (Bio-Rad). Each gel was run initially for $15 \mathrm{~min}$ at $70 \mathrm{~V}$ and $45 \mathrm{~min}$ at $120 \mathrm{~V}$, which was transferred onto PVDF membranes (Bio-Rad) using a Trans-Blot Turbo transfer system for $7 \mathrm{~min}$. Membranes were blocked for $1 \mathrm{~h}$ with 5\% skim milk (Sigma-Aldrich) at room temperature in PBS supplemented with 0.05\% Tween-20 (PBST). Membranes were fractionated in smaller pieces and probed overnight at 4 ${ }^{\circ} \mathrm{C}$ with any of the following specific primary antibodies in PBS Tween 0.05\%: antispike SARS-CoV-2 (GeneTex 1/1000), 
anti-ACE2 (Cell Signaling 1/1000), anti-TMPRSS2 (Thermo Fisher 1/1000), or anti-Vinculin (Sigma-Aldrich 1/10,000) used as loading controls. After three washes in PBST, secondary antibodies, peroxidase-conjugated $\mathrm{F}(\mathrm{ab}) 2$ donkey antimouse $\operatorname{IgG}(\mathrm{H}+\mathrm{L})(1: 10,000)$ or peroxidase-conjugated $\mathrm{F}(\mathrm{ab}) 2$ donkey antirabbit $\operatorname{IgG}(\mathrm{H}+\mathrm{L})(1: 10,000)$ (Jackson ImmunoResearch), were added to the membrane in PBST $1 \%$ milk for $1 \mathrm{~h}$ at room temperature. All membranes were washed three times and exposed using either the SuperSignal West Pico PLUS chemiluminescent substrate or the SuperSignal West Femto maximum sensitivity substrate (Thermo Scientific) and a ChemiDoc imaging system (Bio-Rad).

Flow Cytometry Analysis. The expression of ACE2 and TMPRSS2 was analyzed using flow cytometry. Briefly, $2 \times 10^{5}$ cells were washed with a FACS wash (FW, PBS supplemented with $2 \%$ hiFCS and $1 \mathrm{mM}$ ethylenediaminetetraacetic acid (EDTA) (Thermo Fisher Scientific)) and stained by FW with antibodies for $20 \mathrm{~min}$ on ice in the dark (PerCP mouse antihuman ACE2, clone AC384, Novus Biologicals Cat\#NBP2-80038PCP, or unconjugated rabbit antihuman TMPRSS2, Invitrogen PA5-14264). Cells were then washed twice, and for ACE2 analysis, they were fixated using 1\% formaldehyde (Avantor, VWR, Denmark). For TMPRSS2 expression, samples were incubated with a secondary antibody (Alexa Fluor 488-conjugated goat antirabbit $\operatorname{IgG}(\mathrm{H}+\mathrm{L})$, an absorbed secondary antibody, Invitrogen A-11034) for $20 \mathrm{~min}$ on ice in the dark followed by washing and fixation. The fluorescent intensity was measured with a NovoCyte 3000 analyzer equipped with three lasers (405, 488, and $640 \mathrm{~nm}$ ) and 13 PMT detectors (ACEA Biosciences, Inc). Data were analyzed using De Novo Software FCS Express Flow research edition version 6 . Cells were gated using the following strategy: total cells (SSC-H/FSC-H); single cells (FSC-A/FSC-H); and ACE2 expression or TPMRSS2 expression. For ACE2, unstained samples of the matched cell line were used as a control. For TMPRSS2, secondary antibody-stained samples of the matched cell line were used as a control.

Flow Cytometry Analysis of SARS-Infected Cells. Calu3 cells were seeded in a 24 -well plate $\left(1.5 \times 10^{5} /\right.$ well $)$ and infected the following day with SARS-CoV-2 at an MOI of 0.1 . Following incubation for $48 \mathrm{~h}$, cells were harvested and the LIVE/DEAD Fixable Green Dead Cell Stain kit with $488 \mathrm{~nm}$ excitation (Invitrogen) was used to determine the viability prior fixation with $4 \%$ PFA for $30 \mathrm{~min}$. Then, cells were washed and an anti-SARS-CoV-2 spike S2 mouse monoclonal antibody (GeneTex) was applied at a dilution of 1:3000 in a permeabilizing solution (DPBS (Gibco) and saponin $0.25 \%$ and goat serum $2 \%$ (both Sigma)) for $20 \mathrm{~min}$. After several washes with DPBS, an antimouse Alexa Fluor 555-conjugated secondary antibody (Invitrogen) was applied with the same solution at a dilution of 1:4000 for another $20 \mathrm{~min}$. Cell number acquisition was performed using a NovoCyte Quanteon flow cytometer, and an analysis was performed using NovoExpress Software.

Quantification of Cell Fusion Using Bimolecular Fluorescence (BiFc). Quantification of cell fusion was performed using bimolecular fluorescence complementation $(\mathrm{BiFc})$. Briefly, HEK293T cells were seed in a 12-well microplate $(500,000$ cells/well) in complete media for $24 \mathrm{~h}$. Transient transfection was performed using jetPRIME (Polyplus-transfection, France) according to the manufacturer's instructions. Target cells were transfected with zipV1 $(0.5 \mu \mathrm{g})$, Ace2myc/pCEP4 (0.05 $\mu \mathrm{g})$, and Ace2myc and
TMPRSS2 or zipV1 $(0.5 \mu \mathrm{g})$. The effector cell population was transfected with zipV2 $(0.5 \mu \mathrm{g})$ and SARS-CoV-2 D614G spike/pCAGGs $(0.125 \mu \mathrm{g})$. The total DNA quantity was normalized using empty pCAGGs vector DNA to $1 \mu \mathrm{g}$. Following transfection, cells were incubated at $37{ }^{\circ} \mathrm{C}$ for $24 \mathrm{~h}$. Then, cells were rinsed with PBS and detached with versene (PBS, $0.53 \mathrm{mM}$ EDTA) and counted. Inhibitors or vehicle (DMSO) was added at indicated concentrations (atovaquone 10,50 , and $100 \mu \mathrm{M}$ or camostat $10 \mu \mathrm{M}$ ) with 35,000 cells/well of both populations coseeded in DMEM without serum and phenol red in a 384-well black plate with an optical clear bottom and incubated for $3 \mathrm{~h}$ at $37{ }^{\circ} \mathrm{C}, 5 \% \mathrm{CO}_{2}$. The $\mathrm{BiFc}$ signal was acquired using a BioTek Synergy Neo2 plate reader using a monochromator set to excitation/emission of 500 and $542 \mathrm{~nm}$.

Cytotoxicity Assay (LDH Assay). Cell death was measured by $\mathrm{LDH}$ release using a Pierce $\mathrm{LDH}$ cytotoxicity assay kit (Thermo Fisher) in sextuplicate according to manufacturer's instructions. Untreated cells were used as a negative control, whereas cells lysed with the provided lysis buffer served as a positive control. The LDH activity was measured at 490 and $680 \mathrm{~nm}$ absorbance using a BioTek microplate reader (BioTek Instruments). The $\mathrm{LDH}$ activity was determined by subtracting the background $680 \mathrm{~nm}$ absorbance value from the $490 \mathrm{~nm}$ absorbance value. The $\%$ of cytotoxicity was calculated using the following formula: (LDH activity - LDH activity control)/(LDH activity positive control - LDH activity negative control) $\times 100$.

MTT Assay To Measure Cellular Viability. The redox potential in active mammalian cells reduces MTT to a strongly pigmented formazan product. Following solubilization, the absorbance of formazan can be measured colorimetrically at $570 \mathrm{~nm}$. VeroE6 cells expressing TMPRSS2 were seeded as 1 $\times 10^{4}$ cells per well in a 96-well plate in the presence/absence of $10 \mu \mathrm{M}$ atovaquone or DMSO control. Following an $18 \mathrm{~h}$ incubation, $10 \mu \mathrm{L}$ of $98 \%$ thiazolyl blue tetrazolium bromide (Sigma, M2128) was added to each well and incubated for $4 \mathrm{~h}$. The medium was removed, DMSO was added, and absorbance was measured at $570 \mathrm{~nm}$.

7-Aminoactinomycin D (7-AAD) Assay To Measure Cell Viability by FACS. Caco- 2 and Huh-7 cells were seeded overnight in 24-well plates at $1.2 \times 10^{5}$ cells/well. Cells were then treated with atovaquone $(5-100 \mu \mathrm{M})$ for $48 \mathrm{~h}$. DMSO was used as a negative control. The cell viability was measured by 7-AAD staining: briefly, $48 \mathrm{~h}$ after treatment, the medium was removed, and cells were washed with $1 \times$ PBS and then harvested by trypsinization with $1 \times$ Trypsin-EDTA solution. Cells were then centrifuged at $300 \times g$ and resuspended in 100 $\mu \mathrm{L}$ of $1 \times \mathrm{PBS}$ with $0.125 \mu \mathrm{g}$ of $7-\mathrm{AAD} /$ sample for $5 \mathrm{~min}$ before flow cytometry analysis. Ten thousand events were acquired (BD FACSCanto II, BD Biosciences), and the percentage of dead cells was analyzed using FlowJo software, version 10

Lentiviral SARS-CoV-2 Pseudotype Production and Infection. The SARS-CoV-2 spike gene in expression vector pcDNA3.1 was a gift from Fang Li (Addgene plasmid \# 145032). ${ }^{34}$ The D614G mutation was generated by overlapping PCR and verified by Sanger sequencing. For lentiviral production, HEK293T cells were transiently cotransfected with lentiviral packaging plasmid psPAX2 (gift from Didier 99 Trono, Addgene \#12260), lentiviral vector encoding LacZ (LV-Lac, gift from Inder Verma (Addgene plasmid \# 12108)), ${ }^{35}$ and pcDNA3.1 encoding the D614G SARS-CoV- 
2 spike at a 1:1:1 ratio using a jetPRIME transfection reagent (Polyplus-transfection) according to the manufacturer's protocol. The supernatant containing viral particles was harvested at 48, 72, and $96 \mathrm{~h}$ post-transfection and precleared by filtration with a $0.45 \mu \mathrm{m}$ pore size filter. Virus was concentrated by ultracentrifugation $\left(20,000 \mathrm{rpm}, 1.5 \mathrm{~h}, 4^{\circ} \mathrm{C}\right)$ on a sucrose cushion $(20 \% \mathrm{w} / \mathrm{v})$, and the viral pellet was resuspended in PBS and stored at $-80{ }^{\circ} \mathrm{C}$ until use.

For infection, HEK293T-Ace2 cells were mock-transfected or transfected with plasmid-encoding hTMPRSS2 (Millipore Sigma) using jetPRIME. Twenty-four hours post-transfection, cells were seeded in 96-well plates to achieve approximately $80 \%$ confluence, at which cells were preincubated with the inhibitors (E64d (Millipore Sigma), camostat (Cayman Chemical), atovaquone (Cayman Chemical), or vehicle) and $5 \mu \mathrm{g} / \mathrm{mL}$ polybrene for $1 \mathrm{~h}$ and then incubated with purified SARS-CoV-2 pseudotypes in the presence of the drugs in serum from media. Twenty-four hours post-infection, media were replaced with complete culture media. Seventy-two hours post-infection, cells were either fixed in formalin and staining with X-gal and LacZ+ foci were quantified as described previously, ${ }^{36}$ or LacZ+ cells were quantified using the Beta-Glo assay system (Promega) following the manufacturer's protocol. Luminescence was measured using a Synergy Neo2 MultiMode plate reader (BioTek).

TMPRSS2 Enzymatic Assay. The fluorogenic peptide substrate Boc-Gln-Ala-Arg-AMC (Enzo Life Sciences Inc.) was prepared immediately before use at $10 \mathrm{mM}$ in DMSO and diluted in an assay buffer containing $10 \mu \mathrm{M}$ Boc-Gln-Ala-ArgAMC, $50 \mathrm{mM}$ Tris pH 8.0, $150 \mathrm{mM} \mathrm{NaCl}$, and $0.01 \%$ Tween 20. Solutions were vortexed and $16 \mu \mathrm{L}$ of the master mix was added per well of 384-well black plates (Thermo Fisher) followed by the addition of $2 \mu \mathrm{L}$ of inhibitors (camostat or atovaquone) at $10 \times$ for a final concentration of 1 to $100 \mu \mathrm{M}$. The assay was initiated with $2 \mu \mathrm{L}$ of recombinant active human TMPRSS2 (Cusabio Biotech) at $10 \mu \mathrm{M}$, after which the 384well plate was shaken at $500 \mathrm{rpm}$ for $1 \mathrm{~min}$ for complete mixing. Fluorescence emission was measured with a BioTek Synergy Neo2 plate reader, the excitation wavelength was set at $340 \mathrm{~nm}$, and the emission wavelength was set at $440 \mathrm{~nm}$ every $5 \mathrm{~min}$ or after an incubation of $60 \mathrm{~min}$ at room temperature in the dark.

\section{FUNDING}

This research was funded by the Lundbeck Foundation (R3352019-2138), the Brødrene Hartmann Fond, and the Hørslev Fond to D.O. This research was also supported by a COVID19 Rapid Research grant from the Canadian Institutes for Health Research (OV3 170632) to M.C. K.F. is supported by an Ontario Graduate Scholarship. M.C. is a Canada Research Chair in Molecular Virology and Antiviral Therapeutics and a recipient of an Ontario Early Researcher Award. T.A. was supported by the NSERC Alliance and Mitacs Accelerate COVID-19 as well as CHEO Research Institute COVID-19 funds. J.-S.D. was supported by the Canadian Institutes of Health Research (CIHR) New Investigator Award-Infection and Immunity (INI-147824). J.-S.D. is also recipient of the Ontario Research Fund-COVID-19 Rapid Research Fund grant (project \#C-134-2426131-DIALLO). The views expressed in this study are the views of the recipient and do not necessarily reflect those of the Province. R.M.v.d.S. has received funding from the European Union's Horizon 2020 research and innovation program under the Marie Skłodowska-
Curie grant agreement No 754513 and The Aarhus University Research Foundation. M.R.J. has received funding from the Independent Research Fund Denmark 0214-00001B (SRP), the European Research Council (ERC-AdG ENVISION, 786602), the Lundbeck Foundation grant R349-2020-419 (OSS), the Central Denmark Region grant A3233(OSS), and the Lundbeck Foundation R238-2016-2708. The contributions of J.C.B. and T.A. were supported by the Thistledown Foundation and the Canadian Institutes for Health Research. S.R.P. was supported by the Independent Research Fund Denmark (0214-00001B), and the European Research Foundation (786602).

\section{ASSOCIATED CONTENT}

\section{SI Supporting Information}

The Supporting Information is available free of charge at https://pubs.acs.org/doi/10.1021/acsinfecdis.1c00278.

Case series and supplementary figures including atovaquone reducing SARS-CoV-2 infectivity in Vero hTMPRSS2 and Calu-3 cells, atovaquone but not proguanil reducing the binding between the SARSCoV-2 S1 domain and ACE2, representative dot plots showing the gating strategy to determine ACE2 and TMPRSS2 expression, in vitro TMPRSS2 protease activity assay in the presence of atovaquone, atovaquone not driving SARS-CoV-2 antiviral effect through decreasing mitochondrial activity or depletion of the nucleotide pool contents (PDF)

\section{Accession Codes}

The data that support the findings are available in communication or upon reasonable request from the corresponding author.

\section{AUTHOR INFORMATION}

\section{Corresponding Author}

David Olagnier - Department of Biomedicine, Aarhus University, Aarhus C 8000, Denmark; (1) orcid.org/00000001-6912-0674; Email: olagnier@biomed.au.dk

\section{Authors}

Madalina Elena Carter-Timofte - Department of Biomedicine, Aarhus University, Aarhus C 8000, Denmark

Rozanne Arulanandam - Center for Innovative Cancer Research, Ottawa Hospital Research Institute, Ottawa, Ontario K1H 8L6, Canada

Naziia Kurmasheva - Department of Biomedicine, Aarhus University, Aarhus C 8000, Denmark

Kathy Fu - Department of Biochemistry, Microbiology, and Immunology and Center for Infection, Immunity, and Inflammation, University of Ottawa, Ottawa, Ontario $\mathrm{K} 1 \mathrm{H}$ 8L1, Canada; Ottawa Institute of Systems Biology, Ottawa, Ontario K1H 8L1, Canada

Geneviève Laroche - Department of Biochemistry, Microbiology, and Immunology and Center for Infection, Immunity, and Inflammation, University of Ottawa, Ottawa, Ontario K1H 8L1, Canada; Ottawa Institute of Systems Biology, Ottawa, Ontario K1H 8L1, Canada

Zaid Taha - Center for Innovative Cancer Research, Ottawa Hospital Research Institute, Ottawa, Ontario K1H 8L6, Canada; Department of Biochemistry, Microbiology, and Immunology, University of Ottawa, Ottawa, Ontario $\mathrm{K} 1 \mathrm{H}$ $8 L 1$, Canada 
Demi van der Horst - Department of Biomedicine, Aarhus University, Aarhus C 8000, Denmark

Lena Cassin - Department of Biomedicine, Aarhus University, Aarhus C 8000, Denmark

Renée M. van der Sluis - Department of Biomedicine, Aarhus University, Aarhus C 8000, Denmark; Aarhus Institute of Advanced Studies, Aarhus University, Aarhus 8000, Denmark

Enrico Palermo - Istituto Pasteur Italia-Cenci Bolognetti Foundation, Rome 00161, Italy

Daniele Di Carlo - Istituto Pasteur Italia-Cenci Bolognetti Foundation, Rome 00161, Italy

David Jacobs - Department of Biochemistry, Microbiology, and Immunology and Center for Infection, Immunity, and Inflammation, University of Ottawa, Ottawa, Ontario $\mathrm{K} 1 \mathrm{H}$ 8L1, Canada; Ottawa Institute of Systems Biology, Ottawa, Ontario K1H 8L1, Canada

Glib Maznyi - Center for Innovative Cancer Research, Ottawa Hospital Research Institute, Ottawa, Ontario K1H 8L6, Canada

Taha Azad - Center for Innovative Cancer Research, Ottawa Hospital Research Institute, Ottawa, Ontario K1H 8L6, Canada; Department of Biochemistry, Microbiology, and Immunology, University of Ottawa, Ottawa, Ontario $\mathrm{K} 1 \mathrm{H}$ 8L1, Canada

Ragunath Singaravelu - Center for Innovative Cancer Research, Ottawa Hospital Research Institute, Ottawa, Ontario K1H 8L6, Canada

Fanghui Ren - Department of Biomedicine, Aarhus University, Aarhus C 8000, Denmark

Anne Louise Hansen - Department of Biomedicine, Aarhus University, Aarhus C 8000, Denmark

Manja Idorn - Department of Biomedicine, Aarhus University, Aarhus C 8000, Denmark

Christian K. Holm - Department of Biomedicine, Aarhus University, Aarhus C 8000, Denmark

Martin R. Jakobsen - Department of Biomedicine, Aarhus University, Aarhus C 8000, Denmark

Julien van Grevenynghe - Institut National de la Recherche Scientifique (INRS)-Centre Armand-Frappier Santé Biotechnologie, Laval, Québec H7V 1B7, Canada

John Hiscott - Istituto Pasteur Italia-Cenci Bolognetti Foundation, Rome 00161, Italy

Søren R. Paludan - Department of Biomedicine, Aarhus University, Aarhus C 8000, Denmark

John C. Bell - Center for Innovative Cancer Research, Ottawa Hospital Research Institute, Ottawa, Ontario K1H 8L6, Canada; Department of Biochemistry, Microbiology, and Immunology, University of Ottawa, Ottawa, Ontario $\mathrm{K} 1 \mathrm{H}$ 8L1, Canada

Jean Seguin - CCFP, Dipl. Sport Med., CareMedics McArthur, Ottawa, Ontario K1L 8M3, Canada

Luc A. Sabourin - Center for Innovative Cancer Research, Ottawa Hospital Research Institute, Ottawa, Ontario $\mathrm{K} 1 \mathrm{H}$ 8L6, Canada; Department of Cellular and Molecular Medicine, University of Ottawa, Ottawa, Ontario K1H 8M5, Canada

Marceline Côté - Department of Biochemistry, Microbiology, and Immunology and Center for Infection, Immunity, and Inflammation, University of Ottawa, Ottawa, Ontario $\mathrm{K} 1 \mathrm{H}$ 8L1, Canada; Ottawa Institute of Systems Biology, Ottawa, Ontario K1H 8L1, Canada; (1) orcid.org/0000-0002-46644325
Jean-Simon Diallo - Center for Innovative Cancer Research, Ottawa Hospital Research Institute, Ottawa, Ontario $\mathrm{K} 1 \mathrm{H}$ 8L6, Canada; Department of Biochemistry, Microbiology, and Immunology, University of Ottawa, Ottawa, Ontario K1H 8L1, Canada

Tommy Alain - Department of Biochemistry, Microbiology, and Immunology, University of Ottawa, Ottawa, Ontario K1H 8L1, Canada; Children's Hospital of Eastern Ontario Research Institute, Ottawa, Ontario K1H 8L1, Canada

Complete contact information is available at:

https://pubs.acs.org/10.1021/acsinfecdis.1c00278

\section{Author Contributions}

D.O., T.A., L.A.S., and J.S. were involved in the conceptualization of the study; M.E.C.-T., R.A., N.K., K.F., Z.T., D.v.d.H., L.C., R.M.v.d.S., E.P., D.D.C., D.J., G.M., T.A., R.S., F.R., A.L.H., M.I., and G.L. conducted the experiments; M.C., D.O., and T.A. wrote the manuscript and were involved in original draft preparation; all authors were involved in writing methodological sections, reviewing, and editing of the manuscript; C.K.H., M.R.J., M.C., S.R.P., and J.v.G. helped in procuring critical reagents; D.O. was involved in supervision; D.O., T.A., J.-S.D., M.C., J.C.B., and S.R.P. were involved in funding acquisition; and all authors have read and agreed to the published version of the manuscript.

Notes

The authors declare no competing financial interest.

\section{ACKNOWLEDGMENTS}

The authors also would like to thank Dr. Sean Whelan for sharing VSV pseudotyped with SARS-CoV-2 spike proteins as well as the flow cytometry core facility at Aarhus University, Department of Biomedicine for its technical support.

\section{REFERENCES}

(1) Polack, F. P.; Thomas, S. J.; Kitchin, N.; Absalon, J.; Gurtman, A.; Lockhart, S.; Perez, J. L.; Pérez Marc, G.; Moreira, E. D.; Zerbini, C.; Bailey, R.; Swanson, K. A.; Roychoudhury, S.; Koury, K.; Li, P.; Kalina, W. V.; Cooper, D.; Frenck, R. W., Jr.; Hammitt, L. L.; Türeci, Ö.; Nell, H.; Schaefer, A.; Ünal, S.; Tresnan, D. B.; Mather, S.; Dormitzer, P. R.; Şahin, U.; Jansen, K. U.; Gruber, W. C.; C4591001 Clinical Trial Group. Safety and Efficacy of the BNT162b2 mRNA Covid-19 Vaccine. N. Engl. J. Med. 2020, 383, 2603-2615.

(2) Sadoff, J.; Le Gars, M.; Shukarev, G.; Heerwegh, D.; Truyers, C.; de Groot, A. M.; Stoop, J.; Tete, S.; Van Damme, W.; Leroux-Roels, I.; Berghmans, P. J.; Kimmel, M.; Van Damme, P.; de Hoon, J.; Smith, W.; Stephenson, K. E.; De Rosa, S. C.; Cohen, K. W.; McElrath, M. J.; Cormier, E.; Scheper, G.; Barouch, D. H.; Hendriks, J.; Struyf, F.; Douoguih, M.; Van Hoof, J.; Schuitemaker, H. Interim Results of a Phase 1-2a Trial of Ad26.COV2.S Covid-19 Vaccine. N. Engl. J. Med. 2021, 384, 1824.

(3) Baden, L. R.; el Sahly, H. M.; Essink, B.; Kotloff, K.; Frey, S.; Novak, R.; Diemert, D.; Spector, S. A.; Rouphael, N.; Creech, C. B.; McGettigan, J.; Khetan, S.; Segall, N.; Solis, J.; Brosz, A.; Fierro, C.; Schwartz, H.; Neuzil, K.; Corey, L.; Gilbert, P.; Janes, H.; Follmann, D.; Marovich, M.; Mascola, J.; Polakowski, L.; Ledgerwood, J.; Graham, B. S.; Bennett, H.; Pajon, R.; Knightly, C.; Leav, B.; Deng, W.; Zhou, H.; Han, S.; Ivarsson, M.; Miller, J.; Zaks, T.; COVE Study Group. Efficacy and Safety of the mRNA-1273 SARS-CoV-2 Vaccine. N. Engl. J. Med. 2021, 384, 403-416.

(4) Voysey, M.; Clemens, S. A. C.; Madhi, S. A.; Weckx, L. Y.; Folegatti, P. M.; Aley, P. K.; Angus, B.; Baillie, V. L.; Barnabas, S. L.; Bhorat, Q. E.; Bibi, S.; Briner, C.; Cicconi, P.; Collins, A. M.; ColinJones, R.; Cutland, C. L.; Darton, T. C.; Dheda, K.; Duncan, C. J. A.; Emary, K. R. W.; Ewer, K. J.; Fairlie, L.; Faust, S. N.; Feng, S.; 
Ferreira, D. M.; Finn, A.; Goodman, A. L.; Green, C. M.; Green, C. A.; Heath, P. T.; Hill, C.; Hill, H.; Hirsch, I.; Hodgson, S. H. C.; Izu, A.; Jackson, S.; Jenkin, D.; Joe, C. C. D.; Kerridge, S.; Koen, A.; Kwatra, G.; Lazarus, R.; Lawrie, A. M.; Lelliott, A.; Libri, V.; Lillie, P. J.; Mallory, R.; Mendes, A. V. A.; Milan, E. P.; Minassian, A. M.; McGregor, A.; Morrison, H.; Mujadidi, Y. F.; Nana, A.; O’Reilly, P. J.; Padayachee, S. D.; Pittella, A.; Plested, E.; Pollock, K. M.; Ramasamy, M. N.; Rhead, S.; Schwarzbold, A. V.; Singh, N.; Smith, A.; Song, R.; Snape, M. D.; Sprinz, E.; Sutherland, R. K.; Tarrant, R.; Thomson, E. C.; Török, M. E.; Toshner, M.; Turner, D. P. J.; Vekemans, J.; Villafana, T. L.; Watson, M. E. E.; Williams, C. J.; Douglas, A. D.; Hill, A. V. S.; Lambe, T.; Gilbert, S. C.; Pollard, A. J.; Aban, M.; Abayomi, F.; Abeyskera, K.; Aboagye, J.; Adam, M.; Adams, K.; Adamson, J.; Adelaja, Y. A.; Adewetan, G.; Adlou, S.; Ahmed, K.; Akhalwaya, Y.; Akhalwaya, S.; Alcock, A.; Ali, A.; Allen, E. R.; Allen, L.; Almeida, T. C. D. S. C.; Alves, M. P. S.; Amorim, F.; Andritsou, F.; Anslow, R.; Appleby, M.; Arbe-Barnes, E. H.; Ariaans, M. P.; Arns, B.; Arruda, L.; Azi, P.; Azi, L.; Babbage, G.; Bailey, C.; Baker, K. F.; Baker, M.; Baker, N.; Baker, P.; Baldwin, L.; Baleanu, I.; Bandeira, D.; Bara, A.; Barbosa, M. A. S.; Barker, D.; Barlow, G. D.; Barnes, E.; Barr, A. S.; Barrett, J. R.; Barrett, J.; Bates, L.; Batten, A.; Beadon, K.; Beales, E.; Beckley, R.; Belij-Rammerstorfer, S.; Bell, J.; Bellamy, D.; Bellei, N.; Belton, S.; Berg, A.; Bermejo, L.; Berrie, E.; Berry, L.; Berzenyi, D.; Beveridge, A.; Bewley, K. R.; Bexhell, H.; Bhikha, S.; Bhorat, A. E.; Bhorat, Z. E.; Bijker, E.; Birch, G.; Birch, S.; Bird, A.; Bird, O.; Bisnauthsing, K.; Bittaye, M.; Blackstone, K.; Blackwell, L.; Bletchly, H.; Blundell, C. L.; Blundell, S. R.; Bodalia, P.; Boettger, B. C.; Bolam, E.; Boland, E.; Bormans, D.; Borthwick, N.; Bowring, F.; Boyd, A.; Bradley, P.; Brenner, T.; Brown, P.; Brown, C.; Brown-O’Sullivan, C.; Bruce, S.; Brunt, E.; Buchan, R.; Budd, W.; Bulbulia, Y. A.; Bull, M.; Burbage, J.; Burhan, H.; Burn, A.; Buttigieg, K. R.; Byard, N.; Cabera Puig, I.; Calderon, G.; Calvert, A.; Camara, S.; Cao, M.; Cappuccini, F.; Cardoso, J. R.; Carr, M.; Carroll, M. W.; Carson-Stevens, A.; Carvalho, Y. . M.; Carvalho, J. A. M.; Casey, H. R.; Cashen, P.; Castro, T.; Castro, L. C.; Cathie, K.; Cavey, A.; Cerbino-Neto, J.; Chadwick, J.; Chapman, D.; Charlton, S.; Chelysheva, I.; Chester, O.; Chita, S.; Cho, J. S.; Cifuentes, L.; Clark, E.; Clark, M.; Clarke, A.; Clutterbuck, E. A.; Collins, S. L. K.; Conlon, C. P.; Connarty, S.; Coombes, N.; Cooper, C.; Cooper, R.; Cornelissen, L.; Corrah, T.; Cosgrove, C.; Cox, T.; Crocker, W. E. M.; Crosbie, S.; Cullen, L.; Cullen, D.; Cunha, D. R. M. F.; Cunningham, C.; Cuthbertson, F. C.; da Guarda, S. N. F.; da Silva, L. P.; Damratoski, B. E.; Danos, Z.; Dantas, M. T. D. C.; Darroch, P.; Datoo, M. S.; Datta, C.; Davids, M.; Davies, S. L.; Davies, H.; Davis, E.; Davis, J.; Davis, J.; de Nobrega, M. M. D.; de Oliveira Kalid, L. M.; Dearlove, D.; Demissie, T.; Desai, A.; di Marco, S.; di Maso, C.; Dinelli, M. I. S.; Dinesh, T.; Docksey, C.; Dold, C.; Dong, T.; Donnellan, F. R.; Dos Santos, T.; dos Santos, T. G.; Dos Santos, E. P.; Douglas, N.; Downing, C.; Drake, J.; Drake-Brockman, R.; Driver, K.; Drury, R.; Dunachie, S. J.; Durham, B. S.; Dutra, L.; Easom, N. J. W.; van Eck, S.; Edwards, M.; Edwards, N. J.; el Muhanna, O. M.; Elias, S. C.; Elmore, M.; English, M.; Esmail, A.; Essack, Y. M.; Farmer, E.; Farooq, M.; Farrar, M.; Farrugia, L.; Faulkner, B.; Fedosyuk, S.; Felle, S.; Feng, S.; Ferreira da Silva, C.; Field, S.; Fisher, R.; Flaxman, A.; Fletcher, J.; Fofie, H.; Fok, H.; Ford, K. J.; Fowler, J.; Fraiman, P. H. A.; Francis, E.; Franco, M. M.; Frater, J.; Freire, M. S. M.; Fry, S. H.; Fudge, S.; Furze, J.; Fuskova, M.; Galian-Rubio, P.; Galiza, E.; Garlant, H.; Gavrila, M.; Geddes, A.; Gibbons, K. A.; Gilbride, C.; Gill, H.; Glynn, S.; Godwin, K.; Gokani, K.; Goldoni, U. C.; Goncalves, M.; Gonzalez, I. G. S.; Goodwin, J.; Goondiwala, A.; Gordon-Quayle, K.; Gorini, G.; Grab, J.; Gracie, L.; Greenland, M.; Greenwood, N.; Greffrath, J.; Groenewald, M. M.; Grossi, L.; Gupta, G.; Hackett, M.; Hallis, B.; Hamaluba, M.; Hamilton, E.; Hamlyn, J.; Hammersley, D.; Hanrath, A. T.; Hanumunthadu, B.; Harris, S. A.; Harris, C.; Harris, T.; Harrison, T. D.; Harrison, D.; Hart, T. C.; Hartnell, B.; Hassan, S.; Haughney, J.; Hawkins, S.; Hay, J.; Head, I.; Henry, J.; Hermosin Herrera, M.; Hettle, D. B.; Hill, J.; Hodges, G.; Horne, E.; Hou, M. M.; Houlihan, C.; Howe, E.; Howell, N.; Humphreys, J.; Humphries, H. E.; Hurley, K.; Huson, C.; Hyder-Wright, A.; Hyams, C.; Ikram, S.; Ishwarbhai,
A.; Ivan, M.; Iveson, P.; Iyer, V.; Jackson, F.; de Jager, J.; Jaumdally, S.; Jeffers, H.; Jesudason, N.; Jones, B.; Jones, K.; Jones, E.; Jones, C.; Jorge, M. R.; Jose, A.; Joshi, A.; Júnior, E. A. M. S.; Kadziola, J.; Kailath, R.; Kana, F.; Karampatsas, K.; Kasanyinga, M.; Keen, J.; Kelly, E. J.; Kelly, D. M.; Kelly, D.; Kelly, S.; Kerr, D.; Kfouri, R. . A.; Khan, L.; Khozoee, B.; Kidd, S.; Killen, A.; Kinch, J.; Kinch, P.; King, L. D. W.; King, T. B.; Kingham, L.; Klenerman, P.; Knapper, F.; Knight, J. C.; Knott, D.; Koleva, S.; Lang, M.; Lang, G.; Larkworthy, C. W.; Larwood, J. P. J.; Law, R.; Lazarus, E. M.; Leach, A.; Lees, E. A.; Lemm, N. M.; Lessa, A.; Leung, S.; Li, Y.; Lias, A. M.; Liatsikos, K.; Linder, A.; Lipworth, S.; Liu, S.; Liu, X.; Lloyd, A.; Lloyd, S.; Loew, L.; Lopez Ramon, R.; Lora, L.; Lowthorpe, V.; Luz, K.; MacDonald, J. C.; MacGregor, G.; Madhavan, M.; Mainwaring, D. O.; Makambwa, E.; Makinson, R.; Malahleha, M.; Malamatsho, R.; Mallett, G.; Mansatta, K.; Maoko, T.; Mapetla, K.; Marchevsky, N. G.; Marinou, S.; Marlow, E.; Marques, G. N.; Marriott, P.; Marshall, R. P.; Marshall, J. L.; Martins, F. J.; Masenya, M.; Masilela, M.; Masters, S. K.; Mathew, M.; Matlebjane, H.; Matshidiso, K.; Mazur, O.; Mazzella, A.; McCaughan, H.; McEwan, J.; McGlashan, J.; McInroy, L.; McIntyre, Z.; McLenaghan, D.; McRobert, N.; McSwiggan, S.; Megson, C.; Mehdipour, S.; Meijs, W.; Mendonça, R. N. Á.; Mentzer, A. J.; Mirtorabi, N.; Mitton, C.; Mnyakeni, S.; Moghaddas, F.; Molapo, K.; Moloi, M.; Moore, M.; Moraes-Pinto, M. I.; Moran, M.; Morey, E.; Morgans, R.; Morris, S.; Morris, S.; Morris, H. C.; Morselli, F.; Morshead, G.; Morter, R.; Mottal, L.; Moultrie, A.; Moya, N.; Mpelembue, M.; Msomi, S.; Mugodi, Y.; Mukhopadhyay, E.; Muller, J.; Munro, A.; Munro, C.; Murphy, S.; Mweu, P.; Myasaki, C. H.; Naik, G.; Naker, K.; Nastouli, E.; Nazir, A.; Ndlovu, B.; Neffa, F.; Njenga, C.; Noal, H.; Noé, A.; Novaes, G.; Nugent, F. L.; Nunes, G.; O'Brien, K.; O'Connor, D.; Odam, M.; Oelofse, S.; Oguti, B.; Olchawski, V.; Oldfield, N. J.; Oliveira, M. G.; Oliveira, C.; Oosthuizen, A.; O’Reilly, P.; Osborne, P.; Owen, D. R. J.; Owen, L.; Owens, D.; Owino, N.; Pacurar, M.; Paiva, B. V. B.; Palhares, E. M. F.; Palmer, S.; Parkinson, S.; Parracho, H. M. R. T.; Parsons, K.; Patel, D.; Patel, B.; Patel, F.; Patel, K.; Patrick-Smith, M.; Payne, R. O.; Peng, Y.; Penn, E. J.; Pennington, A.; Peralta Alvarez, M. P.; Perring, J.; Perry, N.; Perumal, R.; Petkar, S.; Philip, T.; Phillips, D. J.; Phillips, J.; Phohu, M. K.; Pickup, L.; Pieterse, S.; Piper, J.; Pipini, D.; Plank, M.; du Plessis, J.; Pollard, S.; Pooley, J.; Pooran, A.; Poulton, I.; Powers, C.; Presa, F. B.; Price, D. A.; Price, V.; Primeira, M.; Proud, P. C.; Provstgaard-Morys, S.; Pueschel, S.; Pulido, D.; Quaid, S.; Rabara, R.; Radford, A.; Radia, K.; Rajapaska, D.; Rajeswaran, T.; Ramos, A. S. F.; Ramos Lopez, F.; Rampling, T.; Rand, J.; Ratcliffe, H.; Rawlinson, T.; Rea, D.; Rees, B.; Reiné, J.; Resuello-Dauti, M.; Reyes Pabon, E.; Ribiero, C. M.; Ricamara, M.; Richter, A.; Ritchie, N.; Ritchie, A. J.; Robbins, A. J.; Roberts, H.; Robinson, R. E.; Robinson, H.; Rocchetti, T. T.; Rocha, B. P.; Roche, S.; Rollier, C.; Rose, L.; Ross Russell, A. L.; Rossouw, L.; Royal, S.; Rudiansyah, I.; Ruiz, S.; Saich, S.; Sala, C.; Sale, J.; Salman, A. M.; Salvador, N.; Salvador, S.; Sampaio, M.; Samson, A. D.; Sanchez-Gonzalez, A.; Sanders, H.; Sanders, K.; Santos, E.; Santos Guerra, M. F. S.; Satti, I.; Saunders, J. E.; Saunders, C.; Sayed, A.; Schim van der Loeff, I.; Schmid, A. B.; Schofield, E.; Screaton, G.; Seddiqi, S.; Segireddy, R. R.; Senger, R.; Serrano, S.; Shah, R.; Shaik, I.; Sharpe, H. E.; Sharrocks, K.; Shaw, R.; Shea, A.; Shepherd, A.; Shepherd, J. G.; Shiham, F.; Sidhom, E.; Silk, S. E.; da Silva Moraes, A. C.; Silva-Junior, G.; Silva-Reyes, L.; Silveira, A. D.; Silveira, M. B. V.; Sinha, J.; Skelly, D. T.; Smith, D. C.; Smith, N.; Smith, H. E.; Smith, D. J.; Smith, C. C.; Soares, A.; Soares, T.; Solórzano, C.; Sorio, G. L.; Sorley, K.; Sosa-Rodriguez, T.; Souza, C. M. C. D. L.; Souza, B. S. D. F.; Souza, A. R.; Spencer, A. J.; Spina, F.; Spoors, L.; Stafford, L.; Stamford, I.; Starinskij, I.; Stein, R.; Steven, J.; Stockdale, L.; Stockwell, L. V.; Strickland, L. H.; Stuart, A. C.; Sturdy, A.; Sutton, N.; Szigeti, A.; Tahiri-Alaoui, A.; Tanner, R.; Taoushanis, C.; Tarr, A. W.; Taylor, K.; Taylor, U.; Taylor, I. J.; Taylor, J.; te Water Naude, R.; Themistocleous, Y.; Themistocleous, A.; Thomas, M.; Thomas, K.; Thomas, T. M.; Thombrayil, A.; Thompson, F.; Thompson, A.; Thompson, K.; Thompson, A.; Thomson, J.; Thornton-Jones, V.; Tighe, P. J.; Tinoco, L. A.; Tiongson, G.; Tladinyane, B.; Tomasicchio, M.; Tomic, A.; Tonks, S.; Towner, J.; 
Tran, N.; Tree, J.; Trillana, G.; Trinham, C.; Trivett, R.; Truby, A.; Tsheko, B. L.; Turabi, A.; Turner, R.; Turner, C.; Ulaszewska, M.; Underwood, B. R.; Varughese, R.; Verbart, D.; Verheul, M.; Vichos, I.; Vieira, T.; Waddington, C. S.; Walker, L.; Wallis, E.; Wand, M.; Warbick, D.; Wardell, T.; Warimwe, G.; Warren, S. C.; Watkins, B.; Watson, E.; Webb, S.; Webb-Bridges, A.; Webster, A.; Welch, J.; Wells, J.; West, A.; White, C.; White, R.; Williams, P.; Williams, R. L.; Winslow, R.; Woodyer, M.; Worth, A. T.; Wright, D.; Wroblewska, M.; Yao, A.; Zimmer, R.; Zizi, D.; Zuidewind, P. Safety and efficacy of the ChAdOx1 nCoV-19 vaccine (AZD1222) against SARS-CoV-2: an interim analysis of four randomised controlled trials in Brazil, South Africa, and the UK. Lancet 2021, 397, 99-111.

(5) Artymowicz, R. J.; James, V. E. Atovaquone: a new antipneumocystis agent. Clin. Pharm. 1993, 12, 563-570.

(6) Kovacs, J. A. Efficacy of atovaquone in treatment of toxoplasmosis in patients with AIDS. The NIAID-Clinical Center Intramural AIDS Program. Lancet 1992, 340, 637-638.

(7) Ling, J.; Baird, J. K.; Fryauff, D. J.; Sismadi, P.; Bangs, M. J.; Lacy, M.; Barcus, M. J.; Gramzinski, R.; Maguire, J. D.; Kumusumangsih, M.; Miller, G. B.; Jones, T. R.; Chulay, J. D.; Hoffman, S. L.; the Naval Medical Research Unit 2 Clinical Trial Team; Naval Medical Research Unit 2 Clinical Trial, Team. Randomized, placebo-controlled trial of atovaquone/proguanil for the prevention of Plasmodium falciparum or Plasmodium vivax malaria among migrants to Papua, Indonesia. Clin. Infect. Dis. 2002, $35,825-833$.

(8) Osei-Akoto, A.; Orton, L.; Owusu-Ofori, S. P.; Cochrane Infectious Diseases Group. Atovaquone-proguanil for treating uncomplicated malaria. Cochrane Database Syst. Rev. 2005, 4, No. CD004529.

(9) Fry, M.; Pudney, M. Site of action of the antimalarial hydroxynaphthoquinone, 2-[trans-4-(4'-chlorophenyl) cyclohexyl]-3hydroxy-1,4-naphthoquinone (566C80). Biochem. Pharmacol. 1992, $43,1545-1553$.

(10) Srivastava, I. K.; Rottenberg, H.; Vaidya, A. B. Atovaquone, a broad spectrum antiparasitic drug, collapses mitochondrial membrane potential in a malarial parasite. J. Biol. Chem. 1997, 272, 3961-3966.

(11) Biagini, G. A.; Viriyavejakul, P.; O’Neill, P. M.; Bray, P. G.; Ward, S. A. Functional characterization and target validation of alternative complex I of Plasmodium falciparum mitochondria. Antimicrob. Agents Chemother. 2006, 50, 1841-1851.

(12) Nixon, G. L.; Moss, D. M.; Shone, A. E.; Lalloo, D. G.; Fisher, N.; O’Neill, P. M.; Ward, S. A.; Biagini, G. A. Antimalarial pharmacology and therapeutics of atovaquone. J. Antimicrob. Chemother. 2013, 68, 977-985.

(13) Seymour, K. K.; Yeo, A. E. T.; Rieckmann, K. H.; Christopherson, R. I. dCTP levels are maintained in Plasmodium falciparum subjected to pyrimidine deficiency or excess. Ann. Trop. Med. Parasitol. 1997, 91, 603-609.

(14) Hammond, D.; Burchell, J.; Pudney, M. Inhibition of pyrimidine biosynthesis de novo in Plasmodium falciparum by 2-(4t-butylcyclohexyl)-3-hydroxy-1,4-naphthoquinone in vitro. Mol. Biochem. Parasitol. 1985, 14, 97-109.

(15) Painter, H. J.; Morrisey, J. M.; Mather, M. W.; Vaidya, A. B. Specific role of mitochondrial electron transport in blood-stage Plasmodium falciparum. Nature 2007, 446, 88-91.

(16) Cifuentes Kottkamp, A.; De Jesus, E.; Grande, R.; Brown, J. A.; Jacobs, A. R.; Lim, J. K.; Stapleford, K. A. Atovaquone Inhibits Arbovirus Replication through the Depletion of Intracellular Nucleotides. J. Virol. 2019, 93, e00389-e00319.

(17) Yamamoto, M.; Ichinohe, T.; Watanabe, A.; Kobayashi, A.; Zhang, R.; Song, J.; Kawaguchi, Y.; Matsuda, Z.; Inoue, J. I. The Antimalarial Compound Atovaquone Inhibits Zika and Dengue Virus Infection by Blocking E Protein-Mediated Membrane Fusion. Viruses 2020, 12, 1475 .

(18) Ko, M.; Chang, S. Y.; Byun, S. Y.; Ianevski, A.; Choi, I.; Pham Hung d'Alexandry d'Orengiani, A. L.; Ravlo, E.; Wang, W.; Bjørås, M.; Kainov, D. E.; Shum, D.; Min, J. Y.; Windisch, M. P. Screening of FDA-Approved Drugs Using a MERS-CoV Clinical Isolate from
South Korea Identifies Potential Therapeutic Options for COVID-19. Viruses 2021, 13, 651.

(19) Karki, R.; Sharma, B. R.; Tuladhar, S.; Williams, E. P.; Zalduondo, L.; Samir, P.; Zheng, M.; Sundaram, B.; Banoth, B.; Malireddi, R. K. S.; Schreiner, P.; Neale, G.; Vogel, P.; Webby, R.; Jonsson, C. B.; Kanneganti, T. D. Synergism of TNF-alpha and IFNgamma Triggers Inflammatory Cell Death, Tissue Damage, and Mortality in SARS-CoV-2 Infection and Cytokine Shock Syndromes. Cell 2021, 184, 149-168.e17.

(20) Jose, R. J.; Manuel, A. COVID-19 cytokine storm: the interplay between inflammation and coagulation. Lancet Respir. Med. 2020, 8, e46-e47.

(21) Del Valle, D. M.; Kim-Schulze, S.; Huang, H. H.; Beckmann, N. D.; Nirenberg, S.; Wang, B.; Lavin, Y.; Swartz, T. H.; Madduri, D.; Stock, A.; Marron, T. U.; Xie, H.; Patel, M.; Tuballes, K.; Van Oekelen, O.; Rahman, A.; Kovatch, P.; Aberg, J. A.; Schadt, E.; Jagannath, S.; Mazumdar, M.; Charney, A. W.; Firpo-Betancourt, A.; Mendu, D. R.; Jhang, J.; Reich, D.; Sigel, K.; Cordon-Cardo, C.; Feldmann, M.; Parekh, S.; Merad, M.; Gnjatic, S. An inflammatory cytokine signature predicts COVID-19 severity and survival. Nat. Med. 2020, 26, 1636-1643.

(22) Castiello, L.; Zevini, A.; Vulpis, E.; Muscolini, M.; Ferrari, M.; Palermo, E.; Peruzzi, G.; Krapp, C.; Jakobsen, M.; Olagnier, D.; Zingoni, A.; Santoni, A.; Hiscott, J. An optimized retinoic acidinducible gene I agonist M8 induces immunogenic cell death markers in human cancer cells and dendritic cell activation. Cancer Immunol. Immunother. 2019, 68, 1479-1492.

(23) Farag, A.; Ping, W.; Boys, I. N.; Jennifer, L. E.; Ohlson, M. B.; Fan, W.; McDougal, M. B.; Ahmed, M.; Schoggins, J. Identification of Atovaquone, Ouabain and Mebendazole as FDA Approved Drugs Targeting SARS-CoV-2 (Version 4). ChemRxiv. 2020.

(24) Azad, T.; Singaravelu, R.; Brown, E. E. F.; Taha, Z.; Rezaei, R.; Arulanandam, R.; Boulton, S.; Diallo, J. S.; Ilkow, C. S.; Bell, J. C. SARS-CoV-2 S1 NanoBiT: A nanoluciferase complementation-based biosensor to rapidly probe SARS-CoV-2 receptor recognition. Biosens. Bioelectron. 2021, 180, No. 113122.

(25) Brown, E. E. F.; Rezaei, R.; Jamieson, T. R.; Dave, J.; Martin, N. T.; Singaravelu, R.; Crupi, M. J. F.; Boulton, S.; Tucker, S.; Duong, J.; Poutou, J.; Pelin, A.; Yasavoli-Sharahi, H.; Taha, Z.; Arulanandam, R.; Surendran, A.; Ghahremani, M.; Austin, B.; Matar, C.; Diallo, J. S.; Bell, J. C.; Ilkow, C. S.; Azad, T. Characterization of Critical Determinants of ACE2-SARS CoV-2 RBD Interaction. Int. J. Mol. Sci. 2021, 22, No. 2268.

(26) Shrimp, J. H.; Kales, S. C.; Sanderson, P. E.; Simeonov, A.; Shen, M.; Hall, M. D. An Enzymatic TMPRSS2 Assay for Assessment of Clinical Candidates and Discovery of Inhibitors as Potential Treatment of COVID-19. ACS Pharmacol. Transl. Sci. 2020, 3, 9971007.

(27) Nguyen, H. T.; Zhang, S.; Wang, Q.; Anang, S.; Wang, J.; Ding, H.; Kappes, J. C.; Sodroski, J. Spike glycoprotein and host cell determinants of SARS-CoV-2 entry and cytopathic effects. J. Virol. 2020, 95, e02304-e02320.

(28) Dittmar, M.; Lee, J. S.; Whig, K.; Segrist, E.; Li, M.; Kamalia, B.; Castellana, L.; Ayyanathan, K.; Cardenas-Diaz, F. L.; Morrisey, E. E.; Truitt, R.; Yang, W.; Jurado, K.; Samby, K.; Ramage, H.; Schultz, D. C.; Cherry, S. Drug repurposing screens reveal cell-type-specific entry pathways and FDA-approved drugs active against SARS-Cov-2. Cell Rep. 2021, 35, No. 108959.

(29) Sanders, J. E.; Buckner, C. D.; Thomas, E. D.; Fleischer, R.; Sullivan, K. M.; Appelbaum, F. A.; Storb, R. Allogeneic marrow transplantation for children with juvenile chronic myelogenous leukemia. Blood 1988, 71, 1144-1146.

(30) Heurich, A.; Hofmann-Winkler, H.; Gierer, S.; Liepold, T.; Jahn, O.; Pohlmann, S. TMPRSS2 and ADAM17 cleave ACE2 differentially and only proteolysis by TMPRSS2 augments entry driven by the severe acute respiratory syndrome coronavirus spike protein. J. Virol. 2014, 88, 1293-1307.

(31) Olagnier, D.; Farahani, E.; Thyrsted, J.; Blay-Cadanet, J.; Herengt, A.; Idorn, M.; Hait, A.; Hernaez, B.; Knudsen, A.; Iversen, 
M. B.; Schilling, M.; Jørgensen, S. E.; Thomsen, M.; Reinert, L. S.; Lappe, M.; Hoang, H. D.; Gilchrist, V. H.; Hansen, A. L.; Ottosen, R.; Nielsen, C. G.; Møller, C.; van der Horst, D.; Peri, S.; Balachandran, S.; Huang, J.; Jakobsen, M.; Svenningsen, E. B.; Poulsen, T. B.; Bartsch, L.; Thielke, A. L.; Luo, Y.; Alain, T.; Rehwinkel, J.; Alcamí, A.; Hiscott, J.; Mogensen, T. H.; Paludan, S. R.; Holm, C. K. SARSCoV2-mediated suppression of NRF2-signaling reveals potent antiviral and anti-inflammatory activity of 4-octyl-itaconate and dimethyl fumarate. Nat. Commun. 2020, 11, 4938.

(32) Reed, L. J.; Muench, H. A simple method of estimating fifty per cent endpoints. Am. J. Epidemiol. 1938, 27, 493-497.

(33) Olagnier, D.; Brandtoft, A. M.; Gunderstofte, C.; Villadsen, N. L.; Krapp, C.; Thielke, A. L.; Laustsen, A.; Peri, S.; Hansen, A. L.; Bonefeld, L.; Thyrsted, J.; Bruun, V.; Iversen, M. B.; Lin, L.; Artegoitia, V. M.; Su, C.; Yang, L.; Lin, R.; Balachandran, S.; Luo, Y.; Nyegaard, M.; Marrero, B.; Goldbach-Mansky, R.; Motwani, M.; Ryan, D. G.; Fitzgerald, K. A.; O’Neill, L. A.; Hollensen, A. K.; Damgaard, C. K.; de Paoli, F. V.; Bertram, H. C.; Jakobsen, M. R.; Poulsen, T. B.; Holm, C. K. Nrf2 negatively regulates STING indicating a link between antiviral sensing and metabolic reprogramming. Nat. Commun. 2018, 9, 3506.

(34) Shang, J.; Ye, G.; Shi, K.; Wan, Y.; Luo, C.; Aihara, H.; Geng, Q.; Auerbach, A.; Li, F. Structural basis of receptor recognition by SARS-CoV-2. Nature 2020, 581, 221-224.

(35) Pfeifer, A.; Brandon, E. P.; Kootstra, N.; Gage, F. H.; Verma, I. M. Delivery of the Cre recombinase by a self-deleting lentiviral vector: efficient gene targeting in vivo. Proc. Natl. Acad. Sci. U. S. A. 2001, 98, $11450-11455$.

(36) Qiu, S.; Leung, A.; Bo, Y.; Kozak, R. A.; Anand, S. P.; Warkentin, C.; Salambanga, F. D. R.; Cui, J.; Kobinger, G.; Kobasa, D.; Côté, M. Ebola virus requires phosphatidylinositol $(3,5)$ bisphosphate production for efficient viral entry. Virology 2018, 513, 17-28. 